\title{
Cellular and Molecular Differences between HFpEF and HFrEF: A Step Ahead in an Improved Pathological Understanding
}

\author{
Steven J. Simmonds ${ }^{1,+}{ }^{\text {, Ilona Cuijpers }}{ }^{1,2,+} \oplus^{+}$, Stephane Heymans ${ }^{1,2,3,4,+}$ and \\ Elizabeth A. V. Jones ${ }^{1,2, *}$ \\ 1 Center for Molecular and Vascular Biology, KU Leuven, Herestraat 49, bus 911, 3000 Leuven, Belgium; \\ steven.simmonds@kuleuven.be (S.J.S.); ilona.cuijpers@kuleuven.be (I.C.); \\ s.heymans@maastrichtuniversity.nl (S.H.) \\ 2 Department of Cardiology, Cardiovascular Research Institute (CARIM), \\ Maastricht University Medical Centre, Universiteitssingel 50, 6229 ER Maastricht, The Netherlands \\ 3 Netherlands Heart Institute, Holland Heart House, Moreelsepark 1, 3511 Utrecht, The Netherlands \\ 4 William Harvey Research Institute, Barts Heart Centre, Queen Mary University of London, \\ Charterhouse Square, London EC1M 6BQ, UK \\ * Correspondence: liz.jones@kuleuven.be; Tel.: +32-16345775 \\ + These authors contributed equally to this work.
}

Academic Editor: Matthijs Blankesteijn

Received: 23 December 2019; Accepted: 15 January 2020; Published: 18 January 2020

\begin{abstract}
Heart failure (HF) is the most rapidly growing cardiovascular health burden worldwide. HF can be classified into three groups based on the percentage of the ejection fraction (EF): heart failure with reduced $\mathrm{EF}(\mathrm{HFrEF})$, heart failure with mid-range-also called mildly reduced EF(HFmrEF), and heart failure with preserved ejection fraction (HFpEF). HFmrEF can progress into either HFrEF or HFpEF, but its phenotype is dominated by coronary artery disease, as in HFrEF. HFrEF and HFpEF present with differences in both the development and progression of the disease secondary to changes at the cellular and molecular level. While recent medical advances have resulted in efficient and specific treatments for HFrEF, these treatments lack efficacy for HFpEF management. These differential response rates, coupled to increasing rates of HF, highlight the significant need to understand the unique pathogenesis of HFrEF and HFpEF. In this review, we summarize the differences in pathological development of HFrEF and HFpEF, focussing on disease-specific aspects of inflammation and endothelial function, cardiomyocyte hypertrophy and death, alterations in the giant spring titin, and fibrosis. We highlight the areas of difference between the two diseases with the aim of guiding research efforts for novel therapeutics in HFrEF and HFpEF.
\end{abstract}

Keywords: heart failure with preserved ejection fraction; heart failure with reduced ejection fraction; inflammation; endothelial dysfunction; cardiomyocyte alterations

\section{Introduction}

Heart failure (HF) is the most prominent cause of hospitalization globally, with 3.6 million newly diagnosed patients annually, resulting in a socioeconomic burden of billions of euros per year [1]. Heart failure with preserved ejection fraction (HFpEF) is a complex cardiovascular syndrome presenting with an ejection fraction (EF) of greater than $50 \%$, along with different pro-inflammatory and metabolic co-morbidities. It is characterised by structural and cellular alterations, including cardiomyocyte hypertrophy, fibrosis, and inflammation, all leading to an inability of the left ventricle to relax properly. In contrast, $\mathrm{HFrEF}$, defined by an $\mathrm{EF}$ of less than $40 \%$, is characterized by substantial cardiomyocyte loss, resulting in the development of systolic dysfunction; in other words, the inability of the left 
ventricle to contract properly. Heart failure with mid-range or mildly reduced EF (HFmrEF), is an intermediate stage, with an EF between $40-49 \%$, that generally progresses either to HFpEF (25\% of cases) or HFrEF (33\% of cases) [2]. With regard to ischaemic aetiology, HFmrEF more resembles HFrEF, but HFmrEF has a higher frequency of underlying coronary artery disease (CAD) and better overall prognosis [2-4].

HFpEF is preceded by chronic comorbidities, such as hypertension, type 2 diabetes mellitus (T2DM), obesity, and renal insufficiency, whereas HFrEF is often preceded by the acute or chronic loss of cardiomyocytes due to ischemia, a genetic mutation, myocarditis, or valvular disease $[5,6]$. This alteration in risk factors already highlights the potential for differing cellular and molecular pathophysiologies of the two diseases. Medical advances have developed efficient and specific treatments of HFrEF by acting on the neuro-humoral axis, but efficacious drugs for the treatment of HFpEF are absent [7]. As a consequence, the prevalence rate of HFrEF has significantly declined over the last few decades, while the prevalence of HFpEF accounts for more than $50 \%$ of all HF cases and is expected to rise even further [8]. These differential response rates to therapies in patients with HFrEF and HFpEF underline their distinct underlying cellular and molecular mechanisms [9].

\section{Differences in Comorbidities/Risk Factors in HFrEF and HFpEF}

Despite the fact that acute cardiovascular events associated with HFrEF and HFpEF share many risk factors [10], some comorbidities differ between them (Table 1, Figure 1). Patients with HFpEF are more likely to be older [11], with a two-fold predominance of females [12]. This predominance of men in HFrEF might be the result of a greater susceptibility to developing myocardial infarction (MI) [11]. Additionally, men more easily develop eccentric left ventricular hypertrophy upon pressure-overload, while concentric hypertrophy is more common in females [13]. Patients with HFpEF have a higher prevalence of non-cardiac comorbidities (i.e., hypertension, T2DM, stroke, anaemia, pulmonary disease, liver disease, sleep apnoea, gout, and cancer) than HFrEF patients [14]. The mortality risk of the comorbidities studied in both types of HF is similar, regardless of the EF [15-17]. Interestingly, in HFpEF, the incidence of hospitalisation for comorbidity-related illness is higher compared to HFrEF [18].

Table 1. Summary of physiological, cellular and molecular similarities and differences between HFrEF and HFpEF.

\begin{tabular}{|c|c|c|}
\hline & HFrEF & HFpEF \\
\hline Comorbidities/risk factors & $\begin{array}{c}\text { Obesity } \\
\text { Hypertension } \\
\text { Diabetes } \\
\text { Kidney disease } \\
\text { Male } \\
\text { Volume overload } \\
\text { Myocarditis } \\
\text { Myocardial infarction } \\
\text { [11] }\end{array}$ & $\begin{array}{c}\text { Obesity } \\
\text { Hypertension } \\
\text { Diabetes } \\
\text { Kidney disease } \\
\text { Female } \\
\text { COPD } \\
\text { Age } \\
\text { Anaemia } \\
\text { Inflammation } \\
\text { Liver disease } \\
\text { Sleep apnoea } \\
\text { Gout } \\
\text { Cancer } \\
\text { [10-12,14] }\end{array}$ \\
\hline Systemic and cardiac inflammation & $\begin{array}{c}\text { Sterile [19] } \\
\text { Non-sterile }[20,21]\end{array}$ & Metabolic-risk induced [9] \\
\hline Endothelial dysfunction & $\begin{array}{c}\text { Late stage symptom [9] } \\
\downarrow \text { Prevalence [22] } \\
\downarrow \text { Microvascular density [23,24] } \\
\downarrow \text { NO bioavailability [25] }\end{array}$ & $\begin{array}{c}\text { Early stage symptom [9] } \\
\uparrow \text { Prevalence [22] } \\
\downarrow \text { Microvascular density [23,24] } \\
\downarrow \downarrow \text { NO bioavailability [25] }\end{array}$ \\
\hline Cardiac hypertrophy & Eccentric [26-30] & Concentric $[31,32]$ \\
\hline Cardiomyocyte cell death & Present $[9,33-36]$ & Absent [37] \\
\hline
\end{tabular}


Table 1. Cont.

\begin{tabular}{|c|c|c|}
\hline & HFrEF & HFpEF \\
\hline Cardiac fibrosis & $\begin{array}{c}\uparrow \text { Perivascular fibrosis [38] } \\
\text { Interstitial fibrosis [39-41] } \\
\text { Replacement fibrosis [42] } \\
\text { Collagen crosslinking? } \\
\text { Fibrotic signalling: } \\
\uparrow \text { Serum TGF } \beta 1 \text { [43] } \\
\downarrow \text { MCP-1 [44-46] }\end{array}$ & $\begin{array}{c}\uparrow \uparrow \text { Perivascular fibrosis [38] } \\
\text { Interstitial fibrosis [39-41] } \\
\uparrow \text { Collagen crosslinking [40] } \\
\text { Fibrotic signalling: } \\
\uparrow \uparrow \text { Serum TGF } \beta 1 \text { [43] } \\
\uparrow \text { MCP-1 [44-46] }\end{array}$ \\
\hline Left ventricular stiffness & $\begin{array}{c}\text { Left ventricular stiffness? [47-53] } \\
\text { Titin: } \\
\text { Cardiomyocyte F Fassive? [54,55] } \\
\uparrow \text { N2BA [56] } \\
\text { Titin dephosphorylation [57] } \\
\text { Titin aggregation [57] } \\
\text { Titin cleavage [58,59] } \\
\text { Cardiac calcium signalling: } \\
\left.\uparrow \text { Myocardial [Na }{ }^{+}\right]_{\text {I }}[60] \\
\downarrow \text { SERCA2a activity [61-65] }\end{array}$ & $\begin{array}{c}\uparrow \text { Left ventricular stiffness [66] } \\
\text { Titin: } \\
\uparrow \text { Cardiomyocyte } \mathrm{F}_{\text {passive }}[54,55] \\
\text { N2BA } \rightarrow \text { N2B }[67-71] \\
\text { N2B hypophosphorylation }[69,72,73] \\
\text { N2Bus hyperphosphorylation at } \mathrm{S} 4185[74] \\
\text { PEVK hyperphosphorylation at S11878 [74] } \\
\text { Cardiac calcium signalling: } \\
\uparrow \text { Myocardial } \mathrm{Ca}^{2+} \text { levels }[75]\end{array}$ \\
\hline
\end{tabular}

$\mathrm{Ca}^{2+}$ (calcium ion), COPD (chronic obstructive pulmonary disease), Fpassive (passive tension), MCP-1 (monocyte chemoattractant protein 1 ), $\mathrm{Na}^{+}$(sodium ion), $\mathrm{NO}$ (nitric oxide), SERCA2a (sarcoplasmic reticulum via Ca ${ }^{2+}$ ATPase 2a), TGF $\beta 1$ (Transforming growth factor beta 1).

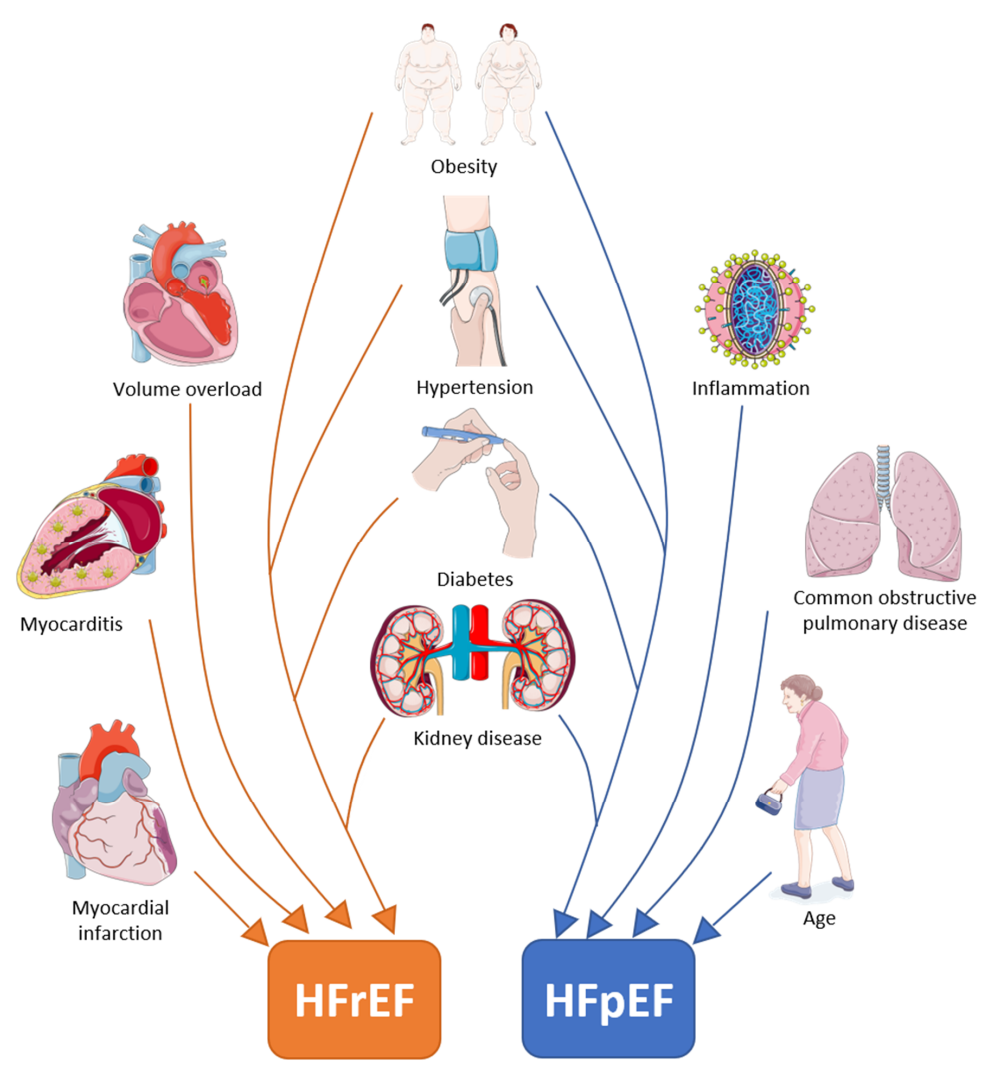

Figure 1. Risk factors and comorbidities involved in the development of either heart failure with reduced ejection fraction, heart failure with preserved ejection fraction or both. Image created using artwork from Servier medical art.

\section{Systemic and Cardiac Inflammation has a Differential Role in HFrEF and HFpEF}

Inappropriate or exaggerated inflammation is a key component underlying damage to the heart in both HFrEF and HFpEF, but has different roles in the onset and propagation. Depending on the trigger, the inflammatory response can be classified into three groups: sterile-, metabolic risk-, and non-sterile-induced inflammation (Table 1, Figure 2). 

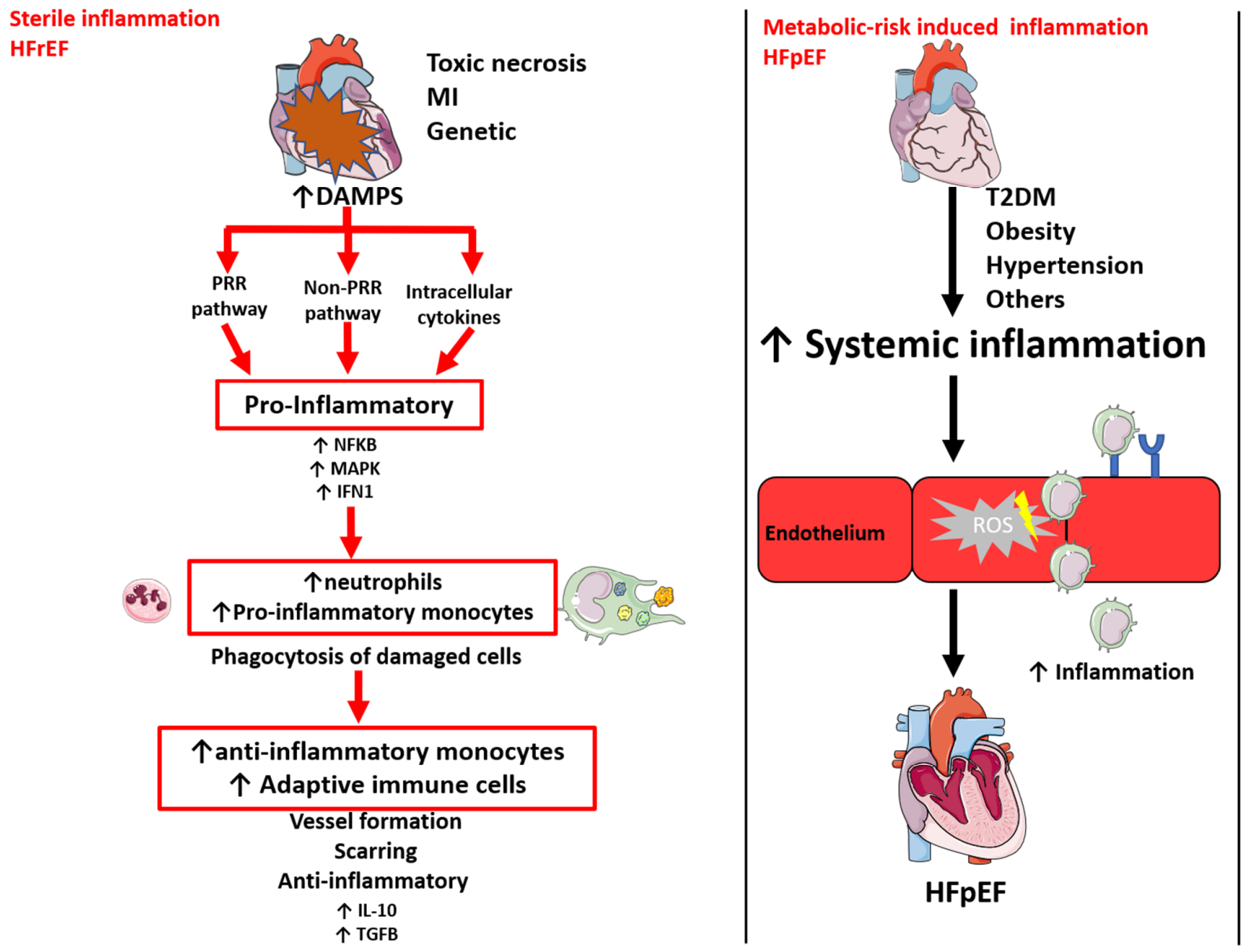

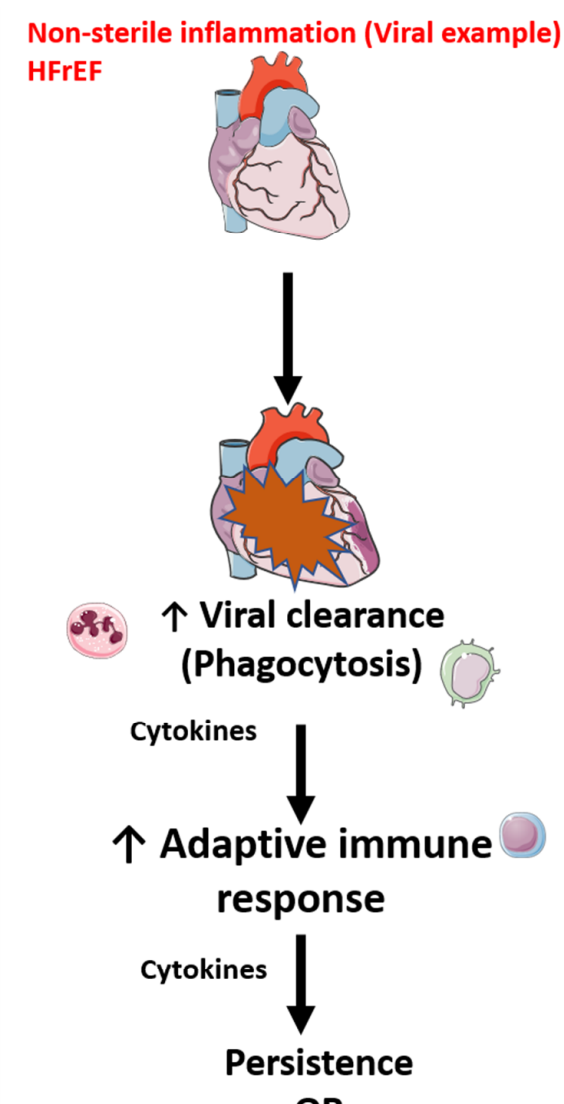

OR

Fibrotic replacement

Figure 2. Schematic of sterile-, metabolic risk-, and non-sterile-induced inflammation in the development of heart failure with reduced ejection fraction and heart failure with preserved ejection fraction. HFpEF (heart failure with preserved ejection fraction), HFrEF (heart failure with reduced ejection fraction), HSC (haemopoietic stem cell), IFN1 (interferon 1), IL-10 (interleukin 10), MAPK (mitogen-activated protein kinase), NFkB (nuclear factor kappa B), PRR (pathogen recognition receptor), T2DM (type 2 diabetes mellitus), ROS (reactive oxygen species), TGF $\beta$ (transforming growth factor beta) Image created using artwork from Servier medical art. 


\subsection{Sterile Inflammation}

Sterile inflammation occurs due to post-ischemic or toxic necrosis, massive trauma, haemorrhage, and/or resuscitation, such as in the HFrEF condition MI [76] (Figure 2). During this response, sterile endogenous stimuli trigger inflammation by a) activating the pathogen recognition receptor (PRR) pathway via the exposure to host-derived non-microbial stimuli released following tissue injury, called damage-associated molecular patterns (DAMPs; e.g., DNA, ATP, and hyaluronan), b) releasing intracellular cytokines, which activate common pathways downstream of PRRs, and/or c) triggering the activation of receptors which are not typically associated with microbial recognition, such as the cluster of differentiation 36 (CD36) [19,77]. Following ligand recognition, PRRs activate downstream signalling, such as transcription factor nuclear factor kappa-B (NFKB), mitogen-activated kinase (MAPK), and type I interferon (IFN), which upregulate pro-inflammatory cytokines and chemokines that are important in the healing response [19]. Furthermore, dying cells release molecules that break the extracellular matrix (ECM) down (matrix metalloproteinases; MMPs), oxidize macromolecules, and induce the production and release of abnormal host cell products, such as heat shock proteins (HSPs) [76,78].

In the meantime, the activation of adrenergic signalling alerts the bone marrow to reduce the production of hematopoietic stem cell (HSC) retention factors [79]. Consequently, HSC and progenitor cells are attracted from their specific niches in the bone marrow by the stromal cell-derived chemokine CXCL12, leading to the production of neutrophils, called granulopoiesis [79]. Neutrophils are rapidly released in the blood and are recruited to the heart, where they phagocytose the damaged cells. Interestingly, the serum neutrophil to lymphocyte ratio is considered a useful marker for the prediction of mortality in patients admitted for ST-segment elevation MI (STEMI) [80]. Furthermore, HSCs egress from the bone marrow and seed in the spleen, thereby triggering extramedullary hemopoiesis and monocyte production [81]. Within $24 \mathrm{~h}$ after MI, the splenic monocyte reservoir is released into the circulation and monocytes are recruited to the heart [82]. Monocytes subsequently infiltrate and produce cytokines and growth factors, such as IL-10 and transforming growth factor $\beta$ (TGF $\beta$ ), to repress inflammatory signalling, promote new blood vessel formation by endothelial cells and vascular smooth muscle cells, and scar formation by (myo)fibroblast activation [83,84]. Furthermore, B- and total and regulatory T-cells are recruited to the heart, where they modulate cardiac remodelling $[19,85,86]$. Regulatory T-lymphocytes have a protective role in ventricular remodelling in MI [86]. As such, the adoptive transfer of regulatory T-cells attenuates inflammation by limiting the local inflammatory response, including reducing immune cell infiltration (T-lymphocytes, macrophages and neutrophils) and pro-inflammatory cytokine production by cardiomyocytes [86]. However, the complex interplay between injured cardiomyocytes and the innate and adaptive immune response is often insufficient to prevent damage to the cardiac contractility.

\subsection{Metabolic Risk-Induced Inflammation}

While the inflammatory response in HFrEF is the result of cardiomyocyte damage, rather than the systemic comorbidities, inflammation in HFpEF is the result of a cluster of extra-cardiac metabolic and inflammatory risk factors, including obesity, diabetes, anaemia, hypertension, chronic obstructive pulmonary disease (COPD), auto-immune diseases, and renal insufficiency [9] (Figure 2). Obese and type 1 and 2 diabetic patients have, for example, elevated levels of advanced glycation end products (AGEs) [87-89]. These AGEs interact with their receptor (RAGE), thereby activating the $\mathrm{NF} \kappa \mathrm{B}$ signalling pathway and secondary pro-inflammatory cytokines, chemokines, and adhesion molecules [90].

The "systemic microvascular paradigm" for HFpEF development proposes that low-grade chronic systemic inflammation initiates detrimental microvascular changes [9]. In line with this, circulating protein levels of pro- inflammatory markers interleukin-6 (IL-6), tumour necrosis factor alpha (TNF- $\alpha$ ), and circulating acute inflammatory C-reactive protein (CRP) were higher and more predictive in HFpEF compared to HFrEF [44,91]. These CRP levels were also proportional to the number of HFpEF-associated comorbidities [92]. Importantly, HFpEF patients also had elevated circulating levels 
of neutrophils and classical, intermediate, and non-classical monocytes, while circulating lymphocytes were not affected $[93,94]$. Correspondingly, the culturing of healthy donor monocytes with serum from patients with HFpEF promoted the differentiation towards alternative activated pro-fibrotic macrophages [94]. In patients with HFpEF, echocardiographic indices of diastolic dysfunction (E/e') correlated with monocyte recruitment in the spleen [93]. This monocyte recruitment to the heart may result in part by increased expression of endothelial adhesion molecules, such as E-selectin and intercellular adhesion molecule 1 (ICAM-1). Their expression is induced directly by comorbidities and indirectly by chronic low-grade inflammation $[25,90,93,95-102]$.

\subsection{Non-sterile inflammation}

Non-sterile inflammation can be induced by a viral infection. Viral myocarditis (VM), for example, is characterized by a cardiac infection caused by a normally benign virus, triggering an exaggerated immune response in immune-susceptible persons. The initial acute phase is characterized by increased circulating and cardiac neutrophils and monocytes, while in later phases, increased circulating T-cells, specifically cytotoxic T-cells, and B-cells can be detected $[20,21]$. This results in scar tissue formation and a reduced contractile function in the chronic phase [21]. VM may result in both systolic and diastolic dysfunction in the long term.

In short, regardless of the cause of HFrEF, inflammation results in cardiac remodelling driven by cardiomyocyte damage or loss, which causes cardiomyocyte autophagy, apoptosis, and necrosis [9,28-30]. In contrast, metabolic risk factors in HFpEF drive the chronic low-grade systemic inflammation along with the increased expression of adhesion molecules on the endothelial cells, leading to systemic and local cardiac inflammation

\section{Endothelial Dysfunction: a Main Player in Both HFrEF and HFpEF}

Endothelial cells represent the majority of non-cardiomyocyte cells $(60 \%)$. Structural and/or functional abnormalities will therefore strongly impact cardiac function [103]. Endothelial dysfunction is an early event in the development of cardiovascular diseases, such as HF, and is therefore an important indicator of survival [104,105]. It is present in both HFpEF and HFrEF (Table 1) [23,24,106], as shown by a similar loss in cardiac microvascular density [23,24]. However, comorbidities can differentially affect endothelial function, with microvascular complications being more prevalent in $\mathrm{HFpEF}$ than in HFrEF [22]. Besides being more severe in HFpEF, endothelial dysfunction happens earlier in the progression of HFpEF. It is therefore an early marker in HFpEF, while being a late stage symptom in HFrEF [9]. Therefore, future research should focus on the early stages of endothelial dysfunction in HFpEF, before the full disease has developed.

Increased oxidative stress, imbalanced nitric oxide (NO) bioavailability, or neurohormonal activation and vasoconstriction in response to reduced cardiac output $(\mathrm{CO})$ are central mechanisms causing endothelial dysfunction [107-113]. Imbalanced NO bioavailability can result from oxidation of $\mathrm{NO}$ and reduced NO production, due to, for example, the uncoupling of endothelial nitric oxide synthase (eNOS), all caused by oxidative stress [9]. HFpEF myocardial biopsies showed reduced NO bioavailability and increased eNOS uncoupling compared to HFrEF patients [25]. Imbalanced NO bioavailability and oxidative stress (nitroso-redox imbalance) subsequently reduce the coronary endothelium-dependent vasodilator capacity [113-115], resulting in impaired myocardial perfusion and coronary flow [113]. Interestingly, in patients with chronic HFrEF, endothelium-mediated vasodilation is an independent predictor of cardiac death and hospitalization, consistent with the notion that endothelium-derived NO might have a protective role in chronic HFrEF [107]. In HFpEF, despite the microvascular paradigm, endothelial dysfunction is not sufficiently well evaluated [9]. Reduced NO signalling is proposed to influence adjacent cardiomyocytes, leading to reduced cyclic guanosine monophosphate (cGMP) and protein kinase G activity (PKG) and increased protein phosphatases 1 and 2a (PP1 and 2a, respectively) activity [25]. This altered signalling is thought to modulate cardiomyocyte hypertrophy and stiffness in HFpEF [9]. 
In addition to an impaired NO bioavailability, there is an association between endothelial dysfunction and reduced endogenous production of estrogens after menopause [116]. Endogenous estrogens have direct and indirect effects on the cardiovascular system. Estrogens directly modulate the vascular tone by a) acute vasodilation by increasing the synthesis of NO [117], b) long-term modulation by regulation of the production of prostaglandins and expression of eNOS and endothelin-1 (ET-1) [118,119], c) inhibition of endothelin-induced vasoconstriction [120], and d) inhibition of sympathetic activity [121]. Furthermore, estrogens have indirect effects on the cardiovascular system by the modulation of cardiovascular risk factors, as women have shown increased total and low-density lipoprotein (LDL) within one year after their final menstrual period [122]. Furthermore, estrogen has anti-proliferative effects on the vascular smooth muscle layer [123], modulates vascular remodelling [124], and exerts anti-oxidative effects [125]. In men with stable HFrEF, both low and high concentrations of circulating estrogen were significant predictors of a poor prognosis [126]. In murine ischemic/reperfusion, estrogen improved functional recovery, decreased cardiomyocyte apoptosis, and necrosis [127]. Notably, HFpEF patients are mostly elderly post-menopausal women, suggesting that a loss of estrogen could partly mediate cardiovascular effects in HFpEF. Interestingly, estradiol administration significantly improved left ventricular diastolic function in hypertensive postmenopausal women with left ventricular diastolic dysfunction [128]. Furthermore, long term exposure to (phyto)estrogen protected against murine HFpEF development [129]. However, the exact mechanism of the lack of estrogen in HFpEF development is unclear.

\section{Cardiomyocyte Alterations in HFrEF and HFpEF: Eccentric Versus Concentric Hypertrophy}

During HFrEF, remodelling is driven by cardiomyocyte damage and loss, leading to an imbalance in the heart wall structure, causing eccentric remodelling, with left ventricular dilation, but a normal wall thickness (Table 1) [26-30]. In contrast, HFpEF patients reveal concentric cardiomyocyte hypertrophy, where the left ventricle wall thickens (Table 1) [31,32]. Remodelling differences in HFrEF and HFpEF can be explained by structural differences in the cardiomyocytes, with thinner and more elongated cardiomyocytes, lower myofibrillar density, and reduced cardiomyocyte passive stiffness $\left(\mathrm{F}_{\text {passive }}\right)$ in cardiac biopsies of HFrEF patients compared to HFpEF patients [54]. Comorbidities found in both HFrEF and HFpEF also differentially alter the structure of the heart; T2DM, for example, causes a more pronounced left ventricular hypertrophy and worsened quality of life in HFpEF compared to HFrEF [22]. Furthermore, increased cardiomyocyte size in the HFpEF biopsies correlates with lower myocardial PKG activity and cGMP concentration [130]. In contrast, circulatory levels of insulin-like growth factor 1 (IGF-1), a vasoprotective hormone, which stimulates myocardial contractility, were reduced in HFrEF compared to HFpEF [131], suggesting a reduced protection of cardiomyocytes from oxidative and hypertrophic stress $[9,132]$. Thus, differences in stimuli and altered cellular signalling contribute to the distinct types of cardiac hypertrophy observed in HFrEF and HFpEF.

\section{Cardiomyocyte Cell Death: a Typical Characteristic of HFrEF}

Cardiomyocyte damage in HFrEF patients, indicated by increased circulating levels of Troponin-T, leads to a reduction in functioning cardiomyocyte mass in combination with excessive fibrotic tissue [9,33-36]. Cardiomyocyte loss during HFrEF occurs by apoptosis, necrosis, necroptosis, or autophagy depending on the underlying cause [133]. Ischemia induces both apoptosis and necrosis [134]. In VM, an inappropriate inflammatory response causes cardiomyocyte loss [20]. Pressure-overload may also induce cardiomyocyte apoptosis, in part by the pro-apoptotic FAS (also known as apoptosis antigen 1), its ligand, caspase-8, and its cleavage enzyme [34,135]. Additionally, in a type 1 diabetes mellitus (T1DM)-induced model of diabetic cardiomyopathy, mitochondrial regulatory proteins were upregulated during HFrEF, suggesting mitochondrial dysregulation, which could lead to further cardiomyocyte apoptosis [136]. Cardiac steatosis is reported in both HFrEF and HFpEF patients and models, and is also hypothesized to cause cardiomyocyte apoptosis $[137,138]$. Lipid exposure has been shown to cause cardiomyocyte apoptosis in vitro [139]; however, current studies show 
conflicting evidence in vivo [140-142]. Recent evidence has suggested that cardiomyocyte autophagy and necroptosis (a controlled form of necrosis) play a larger role than apoptosis [143]. Interestingly, even low levels of cardiomyocyte apoptosis induce HFrEF in animal models [144]. In contrast, circulating Troponin-T, which indicates elevated levels of cardiomyocyte cell death, was not detected in HFpEF patients [37]. However, in a rat model of HFpEF, the inhibition of apoptotic and autophagic genes improved diastolic dysfunction, even though there was no evidence of decreased apoptosis or autophagy [145]. Thus, though cardiomyocyte cell death is a characteristic observed in HFrEF and not in HFpEF (Table 1), these data suggest that apoptosis and autophagy pathways may also play a role in cardiomyocyte hypertrophy and stiffening during HFpEF, without leading to cardiomyocyte death.

\section{Different Types of Cardiac Fibrosis in HFrEF and HFpEF}

In the healthy heart, the ECM is mainly composed of thicker collagen type I fibres ( $85 \%)$, which confer tensile strength, and thin collagen type III fibres ( 11\%), that maintain the elasticity of the matrix network [146]. In addition to collagens, the cardiac ECM also contains glycosaminoglycans (e.g., hyaluronan), glycoproteins (e.g., SPARC, thrombospondin, fibrillin and fibronectin), and proteoglycans (e.g., syndecan, osteoglycin). Under pathophysiological stresses, such as aging, hypertension, T2DM, myocardial injury, toxic insults, and pressure overload, augmented cardiac fibrosis develops (Table 1). In HFrEF, cardiac fibrosis is mainly the consequence of cardiomyocyte loss and may contribute to systolic dysfunction via several mechanisms. First, the loss of fibrillar collagen may impair the transduction of cardiomyocyte contraction into myocardial force, resulting in the uncoordinated contraction of cardiomyocyte bundles [147]. Second, cardiac fibrosis impairs interactions between endomysial components such as laminin, which connect adjacent cardiomyocytes and capillaries, and their receptors, thereby disrupting the cardiomyocyte mass and systolic reserve [148]. This contrasts with $\mathrm{HFpEF}$, where excessive collagen deposition and a reduction of the more flexible collagen III results in increased cardiac stiffness [40,149].

Activated myofibroblasts, important players in the fibrotic processes, are increased in the myocardium during HFrEF (e.g., MI and pressure-overload) and HFpEF-associated comorbidities (e.g., T2DM, and aging) [150-153]. Despite showing myofibroblast accumulation, the signals which control fibrosis are different. In the healthy heart, TGF $\beta 1$, a central mediator in fibrogenesis, is present as a latent complex, but is activated during cardiac injury by a wide range of mediators, such as proteases (e.g., plasmin, MMP-9), thrombospondin-1 (TSP-1), integrins, and ROS [154-157]. Interestingly, the ratios of plasma levels of MMP-9 to tissue inhibitor of MMP-1 (TIMP-1) were higher in HFrEF compared to HFpEF patients, while no differences were found in MMP-9 levels in HFrEF versus HFpEF [158]. This suggests that this differential MMP/TIMP signaling in HFrEF and HFpEF might result in distinctive TGF $\beta 1$ signalling. TGF $\beta 1$ signalling subsequently activates genes responsible for myofibroblast transdifferentiation and ECM synthesis, thereby increasing fibrosis. Patients with HFpEF exhibited higher serum concentrations of the pro-fibrotic TGF $\beta 1$ protein compared to HFrEF patients [43]. In addition, chemokines, such as monocyte chemoattractant protein 1 (MCP-1/CLL-2) recruit pro-fibrotic leukocyte subpopulations, fibroblasts progenitors, and control fibroblast behaviour [159-162]. HFpEF patients have increased MCP-1/CLL-2 serum levels, which are reduced in HFrEF [44-46].

The effects of cardiac fibrosis are not solely due to amount of collagen deposited, but also the location. Perivascular fibrosis develops as a response to the production of pro-fibrotic proteins (e.g., TGF $\beta$ ) by infiltrated immune cells close to the vasculature [9]. This fibrosis is the consequence of a systemic and cardiac inflammation in both HFpEF and HFrEF, but is significantly greater in HFpEF [38]. Interstitial fibrosis is characterized by the expansion of the ECM surrounding the cardiomyocytes, occurring in HF without cardiomyocyte loss [163], including non-ischemic HFrEF and HFpEF [39-41]. Unlike other organs, the heart has a very limited regenerative capacity, therefore repair processes involving the removal of necrotic cardiomyocytes followed by replacement fibrosis aim to preserve myocardial structural and functional integrity [164]. In the early inflammatory phase after MI, a temporary fibrin matrix (granulation tissue) is formed to replace dead cells [42]. In the subsequent 
phases, this is replaced by a collagen-based matrix, leading to the development of a mature scar, which is mostly devoid of cardiomyocytes. This mature scar consists of a mature dense collagen network (mainly collagen I and III) containing fibroblasts, immune cells, and microvessels [42,165]. Cardiomyocyte loss is predominant in $\mathrm{HFrEF}$, and not reported in $\mathrm{HFpEF}$, as described before, therefore this type of replacement fibrosis is only present in HFrEF.

Collagen crosslinking is also relevant to fibrotic disease pathophysiology, as it is differentially regulated between HFrEF and HFpEF. HFpEF patients show increased collagen cross-linking and upregulation of the collagen crosslinker lysyl-oxidase (LOX), associated with impaired diastolic tissue Doppler parameters (e.g., E/E') [40]. Currently, no studies have measured levels of LOX in HFrEF; however, trials using crosslink breakers showed a decrease in left ventricular stiffness in HFpEF patients, but no efficacy, and even increased cardiac dilatation in HFrEF patients [166,167]. Secreted ECM glycoproteins and proteoglycans also modulate collagen properties. Plasma syndecan-1 levels correlate with cardiac fibrosis in patients with HFpEF and HFrEF and were independently associated with clinical outcomes in patients with HFpEF but not in patients with HFrEF [168]. Furthermore, SPARC is involved in post-synthetic procollagen processing and the formation of mature cross-linked collagen fibrils in pressure-overloaded and aged hearts $[169,170]$. Lastly, osteoglycin negatively regulates cardiac fibrotic remodelling by attenuating cardiac myofibroblast proliferation and migration [171]. Thus, differences in the localization, composition, and crosslinking of the cardiac fibrous tissue contribute to the differences in HFrEF and HFpEF.

\section{Left Ventricular Stiffness in HFrEF and HFpEF: Cardiac Titin and $\mathrm{Ca}^{2+}$ Levels are Differently Affected in HFpEF and HFrEF}

Increased left ventricular stiffness leading to diastolic dysfunction is a hallmark of HFpEF [66]. However, HFrEF risk factors also alter left ventricular stiffness (Table 1). For example, patients with CAD or MI had an impaired active relaxation $[50,172]$. In rats, chronic coronary occlusion initially prolonged relaxation, which returned to normal after one hour of occlusion until five days after MI and then increased permanently, similarly to the HFpEF phenotype [173]. In patients with MI, left ventricular stiffness may vary, going from normal, to increased, or even reduced levels [47-52]. Patients with end-stage non-ischemic dilated cardiomyopathy showed reduced left ventricular stiffness [53]. Changes in ventricular stiffness arise not only from cardiac fibrosis (discussed above), but also from cardiomyocyte $\mathrm{F}_{\text {passive }}[66,174,175]$. Cardiomyocytes from HFpEF patients have a significant increase in $\mathrm{F}_{\text {passive, }}$ when compared to those from $\mathrm{HFrEF}$ patients $[54,55]$. Changes in cardiomyocyte $\mathrm{F}_{\text {passive }}$ occur through several mechanisms which are alternatively regulated between HFrEF and HFpEF.

\subsection{Titin Modifications in HFrEF and HFpEF}

Titin, a bidirectional giant spring, is the main determinant of cardiomyocyte $\mathrm{F}_{\text {passive. Alternative }}$ splicing of titin mRNA generates two isoforms: the shorter but stiffer N2B, and the longer more flexible N2BA (Figure 3A). Animal models for HFpEF, obesity, T1DM, T2DM, and hypertension, showed isoform switching from the more flexible N2BA to the stiffer N2B, which is associated with an increased $\mathrm{F}_{\text {passive }}$ [67-71]. In contrast, in cardiac biopsies from HFrEF patients, the flexible N2BA isoform was increased, while total titin levels were unchanged, indicating a switch from the stiffer N2B to the more flexible N2BA isoform and a reduced $\mathrm{F}_{\text {passive }}$ [56]. 
A

\section{Flexible}

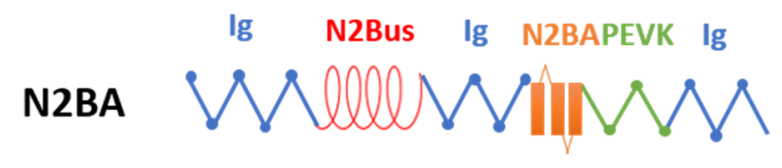

\section{Stiff}

Ig N2Bus PEVK Ig

N2B

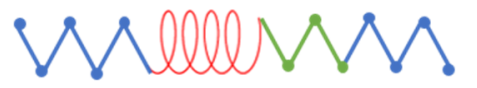

B

Titin post-translational modifications

\section{HFrEF}

$\uparrow$ dephosphorylation

$\uparrow$ aggregation

$\uparrow$ cleavage

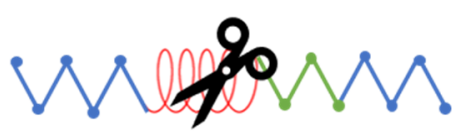

?? Left ventricular stiffness

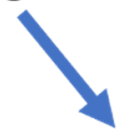

HFpEF

$\downarrow$ Total N2B isoform phosphorylation

$\downarrow$ N2Bus phosphorylation (S4185)

$\uparrow$ PEVK phosphorylation

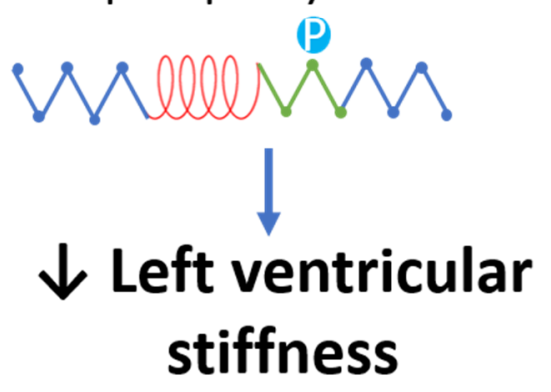

Figure 3. The role of titin in left ventricular stiffness. (A) Diagram of the alternative isoforms of titin. (B) Post-translational modifications of Titin and their effect on left ventricular stiffness in HFrEF and HFpEF.

In contrast to isoform shifts, post-translation modifications of titin provide a more rapid mechanism to affect cardiomyocyte's $F_{\text {passive }}$ (Figure 3B). Hypophosphorylation of total N2B isoform increased cardiomyocyte $F_{\text {passive }}$ in human HFpEF biopsies and animal models for HFpEF [69,72,73]. The in vitro administration of protein kinase $A$ (PKA) decreased $F_{\text {passive }}$ in human cardiomyocytes by increasing the phosphorylation of N2B [176]. Furthermore, site-specific phosphorylation of titin in different regions, including the N2B unique sequence (N2Bus) and a region rich in proline, glutamate, valine, and lysine (PEVK), affects cardiomyocyte $F_{\text {passive }}$ [177]. In patients with HFpEF and hypertension, titin was hypophosphorylated at S4185 (PKG/PKA site in N2Bus), but hyperphosphorylated at S11878 (PKC $\alpha$ site in PEVK) compared to non-hypertensive HFpEF patients and control subjects [74]. In patients with HFrEF, titin dephosphorylation and aggregation ex vivo were also partially responsible for increased $\mathrm{F}_{\text {passive, }}$, which could increase overall cardiac stiffness [57]. Interestingly, truncated titin variants in HFrEF patients promoted cardiac functional and structural alterations [58]. In myocardial 
ischemia/reperfusion injury, the protease MMP-2 cleaved titin [59], suggesting a role of proteolysis in decreasing cardiomyocyte passive stiffness during HFrEF.

\subsection{Cardiac $\mathrm{Ca}^{2+}$ Levels in HFpEF and HFrEF}

Cardiac relaxation also depends on a decreased level of intracellular calcium $\left(\mathrm{Ca}^{2+}\right)$. Sequestration of cytoplasmic $\mathrm{Ca}^{2+}$ mainly occurs through active $\mathrm{Ca}^{2+}$ uptake by the sarcoplasmic reticulum (SR) via $\mathrm{Ca}^{2+}$ ATPase 2a (SERCA2a). Extrusion to the extracellular space via $\mathrm{Na}^{+} / \mathrm{Ca}^{2+}$ exchanger (NCX), sacrolemmal SERCA, and mitochondria are also involved [178-181]. In HFrEF, impaired $\mathrm{Ca}^{2+}$ release from the SR leads to systolic dysfunction, as cardiac contraction depends on a transient increase in $\left[\mathrm{Ca}^{2+}\right]_{I}$ to activate cross-bridge formation between myofilament proteins. For example, patients with end-stage HFrEF have elevated myocardial $\left[\mathrm{Na}^{+}\right]_{\mathrm{I}}[60]$. Small increases in $\left[\mathrm{Na}^{+}\right]_{I}$ may increase the $\mathrm{Ca}^{2+}$ influx via reverse mode NCX and limit the $\mathrm{Ca}^{2+}$ extrusion via forward mode $\mathrm{NCX}$, leading to elevated levels of sub-sarcolemmal $\left[\mathrm{Ca}^{2+}\right]_{\mathrm{I}}[182]$. Furthermore, both reduced SERCA2a activity and inhibition of SERCA2 by phospholamban are observed in HFrEF, leading to reduced $\mathrm{Ca}^{2+}$ removal [61-65]. Myocardial $\mathrm{Ca}^{2+}$ levels are increased in patients with $\mathrm{HFpEF}$, indicating reduced $\mathrm{Ca}^{2+}$ removal, as observed in HFrEF. However, unlike HFrEF, this deficit in $\mathrm{Ca}^{2+}$ removal in HFpEF is not dependent on the $\mathrm{Na}^{+}$gradient [75]. These results highlight how slight changes in ion handling have a profound effect on cardiac function.

\section{Conclusions}

Despite the fact that HFrEF and HFpEF share many risk factors and co-morbidities, there are substantial differences in systemic inflammation, cardiac remodelling (endothelial function, hypertrophy, and cardiomyocyte cell death), and stiffness (fibrosis, titin, and calcium levels). HFrEF, mostly occurs in male patients and is the consequence of cardiomyocyte loss. In contrast, HFpEF is often diagnosed in elderly female patients, who suffer from (a cluster of) non-cardiac comorbidities, such as hypertension, T2DM, stroke, anaemia, pulmonary disease, liver disease, sleep apnoea, gout, and cancer. HFpEF is characterized by low-grade chronic systemic inflammation and capillary dysfunction, with consequential low-grade cardiac inflammation. However, as most studies are conducted on models of established HFpEF, studies during the disease onset are required to elucidate the common denominator underlying the associated complications for HFpEF. In HFrEF, systemic and cardiac inflammation are secondary to the causes of cardiomyocyte loss. Whereas in HFpEF endothelial dysfunction mainly precedes its progression, in HFrEF endothelial dysfunction may rather be the consequence. Depending on the stimulus, perivascular (metabolic risks in HFpEF), interstitial (e.g., aging, hypertension in both HFpEF and HFrEF), or replacement (e.g., MI in HFrEF) fibrosis occurs and is differentially managed between the two conditions. The increased left ventricular stiffness in HFpEF is caused by reduced $\mathrm{Ca}^{2+}$ signalling, titin modifications (isoform shifts towards the stiffer isoform and post-translational changes), and increased perivascular and interstitial fibrosis. In contrast, in $\mathrm{HFrEF}$, titin isoform switching is less consistent, and more flexible isoforms even present in end-stage non-ischemic dilated cardiomyopathy, therefore left ventricular stiffness ranges from being unaffected, to increased, or even reduced.

Author Contributions: I.C. and S.J.S. researched data for the article, wrote the manuscript, and edited the critical comments and editorial changes of the other authors. S.H. and E.A.V.J. reviewed the manuscript. All authors have read and agreed to the published version of the manuscript.

Funding: This work was supported by European Research Area Networks on Cardiovascular Diseases (ERA-CVD) [LYMIT-DIS, 2016] and Fonds Wetenschappelijk Onderzoek [1160718N, 9091018N, G091018N]. SH is supported by the ERA-Net-CVD project MacroERA [01KL1706, 2016] and IMI2-CARDIATEAM [N 821508], by support from the Netherlands Cardiovascular Research Initiative, an initiative with support of the Dutch Heart Foundation, CVON2016-Early HFPEF 2015-10, CVON She-PREDICTS, grant 2017-21, CVON Arena-PRIME, and 2017-18.

Acknowledgments: The figures were created using Servier Medical Art templates, which are licensed under a Creative Commons Attribution 3.0 Unported License; https://smart.servier.com. 
Conflicts of Interest: The authors declare no conflict of interest.

\section{Abbreviations}

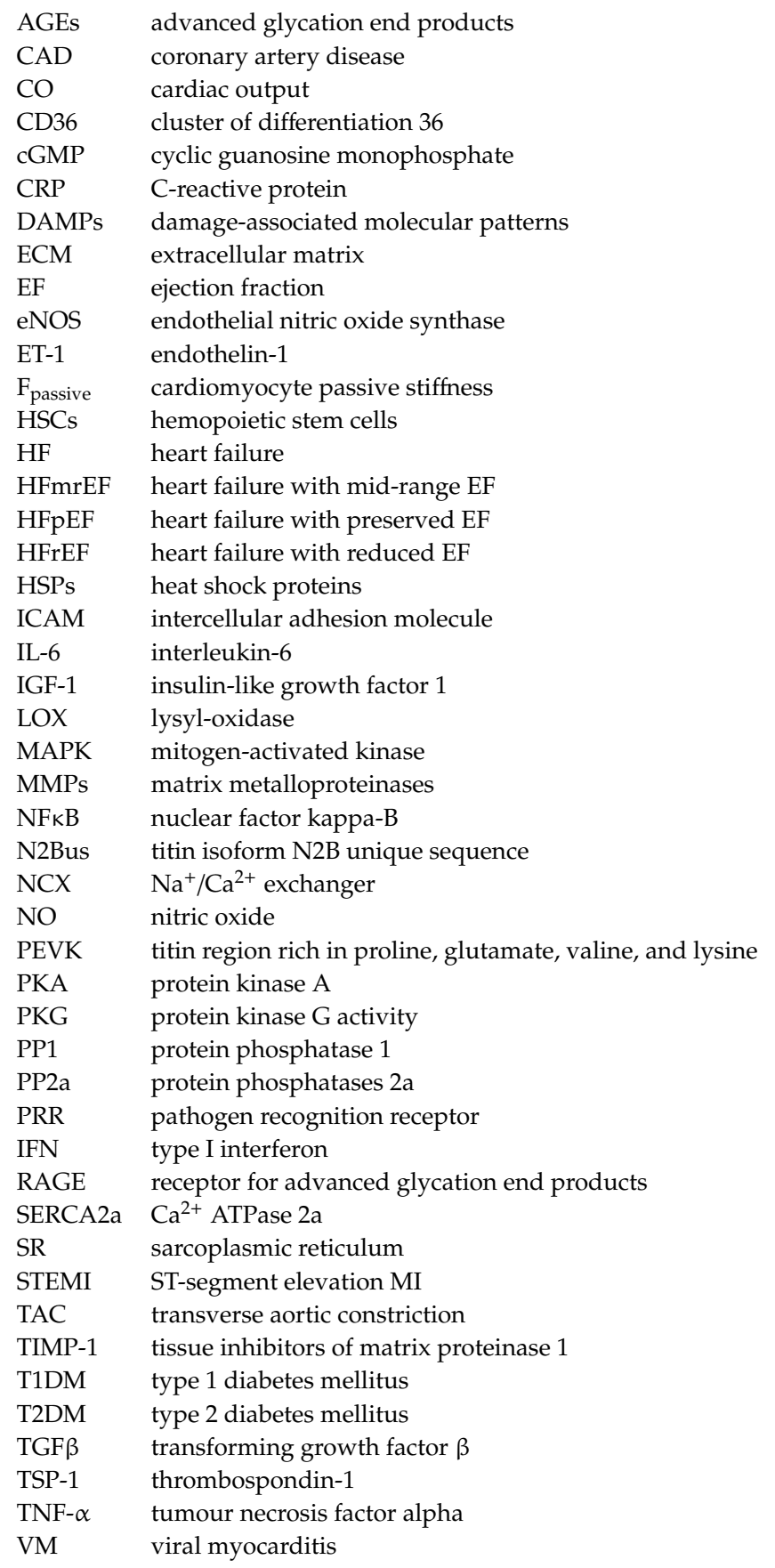

\section{References}

1. Ambrosy, A.P.; Fonarow, G.C.; Butler, J.; Chioncel, O.; Greene, S.J.; Vaduganathan, M.; Nodari, S.; Lam, C.S.; Sato, N.; Shah, A.N.; et al. The global health and economic burden of hospitalizations for heart failure: Lessons learned from hospitalized heart failure registries. J. Am. Coll. Cardiol. 2014, 63, 1123-1133. [CrossRef] [PubMed]

2. Vedin, O.; Lam, C.S.P.; Koh, A.S.; Benson, L.; Teng, T.H.K.; Tay, W.T.; Braun, O.O.; Savarese, G.; Dahlstrom, U.; Lund, L.H. Significance of Ischemic Heart Disease in Patients With Heart Failure and Preserved, Midrange, and Reduced Ejection Fraction: A Nationwide Cohort Study. Circ. Heart Fail 2017, 10. [CrossRef] [PubMed] 
3. Koh, A.S.; Tay, W.T.; Teng, T.H.K.; Vedin, O.; Benson, L.; Dahlstrom, U.; Savarese, G.; Lam, C.S.P.; Lund, L.H. A comprehensive population-based characterization of heart failure with mid-range ejection fraction. Eur. J. Heart Fail 2017, 19, 1624-1634. [CrossRef] [PubMed]

4. Kapoor, J.R.; Kapoor, R.; Ju, C.; Heidenreich, P.A.; Eapen, Z.J.; Hernandez, A.F.; Butler, J.; Yancy, C.W.; Fonarow, G.C. Precipitating Clinical Factors, Heart Failure Characterization, and Outcomes in Patients Hospitalized With Heart Failure With Reduced, Borderline, and Preserved Ejection Fraction. JACC Heart Fail 2016, 4, 464-472. [CrossRef] [PubMed]

5. He, J.; Ogden, L.G.; Bazzano, L.A.; Vupputuri, S.; Loria, C.; Whelton, P.K. Risk factors for congestive heart failure in US men and women: NHANES I epidemiologic follow-up study. Arch. Intern. Med. 2001, 161, 996-1002. [CrossRef]

6. Borlaug, B.A.; Melenovsky, V.; Russell, S.D.; Kessler, K.; Pacak, K.; Becker, L.C.; Kass, D.A. Impaired chronotropic and vasodilator reserves limit exercise capacity in patients with heart failure and a preserved ejection fraction. Circulation 2006, 114, 2138-2147. [CrossRef]

7. Kass, D.A.; Bronzwaer, J.G.; Paulus, W.J. What mechanisms underlie diastolic dysfunction in heart failure? Circ. Res. 2004, 94, 1533-1542. [CrossRef]

8. Tsao, C.W.; Lyass, A.; Enserro, D.; Larson, M.G.; Ho, J.E.; Kizer, J.R.; Gottdiener, J.S.; Psaty, B.M.; Vasan, R.S. Temporal Trends in the Incidence of and Mortality Associated With Heart Failure With Preserved and Reduced Ejection Fraction. JACC Heart Fail 2018, 6, 678-685. [CrossRef]

9. Paulus, W.J.; Tschope, C. A novel paradigm for heart failure with preserved ejection fraction: Comorbidities drive myocardial dysfunction and remodeling through coronary microvascular endothelial inflammation. J. Am. Coll. Cardiol. 2013, 62, 263-271. [CrossRef]

10. Jeong, E.M.; Dudley, S.C., Jr. Diastolic dysfunction. Circ. J. 2015, 79, 470-477. [CrossRef]

11. Ho, J.E.; Lyass, A.; Lee, D.S.; Vasan, R.S.; Kannel, W.B.; Larson, M.G.; Levy, D. Predictors of new-onset heart failure: Differences in preserved versus reduced ejection fraction. Circ. Heart Fail 2013, 6, 279-286. [CrossRef] [PubMed]

12. Lee, D.S.; Gona, P.; Vasan, R.S.; Larson, M.G.; Benjamin, E.J.; Wang, T.J.; Tu, J.V.; Levy, D. Relation of disease pathogenesis and risk factors to heart failure with preserved or reduced ejection fraction: Insights from the framingham heart study of the national heart, lung, and blood institute. Circulation 2009, 119, 3070-3077. [CrossRef] [PubMed]

13. Krumholz, H.M.; Larson, M.; Levy, D. Sex differences in cardiac adaptation to isolated systolic hypertension. Am. J. Cardiol. 1993, 72, 310-313. [CrossRef]

14. Ergatoudes, C.; Schaufelberger, M.; Andersson, B.; Pivodic, A.; Dahlstrom, U.; Fu, M. Non-cardiac comorbidities and mortality in patients with heart failure with reduced vs. preserved ejection fraction: A study using the Swedish Heart Failure Registry. Clin. Res. Cardiol. 2019, 108, 1025-1033. [CrossRef] [PubMed]

15. Ather, S.; Chan, W.; Bozkurt, B.; Aguilar, D.; Ramasubbu, K.; Zachariah, A.A.; Wehrens, X.H.; Deswal, A. Impact of noncardiac comorbidities on morbidity and mortality in a predominantly male population with heart failure and preserved versus reduced ejection fraction. J. Am. Coll. Cardiol. 2012, 59, 998-1005. [CrossRef] [PubMed]

16. Felker, G.M.; Shaw, L.K.; Stough, W.G.; O'Connor, C.M. Anemia in patients with heart failure and preserved systolic function. Am. Heart J. 2006, 151, 457-462. [CrossRef] [PubMed]

17. Smith, D.H.; Thorp, M.L.; Gurwitz, J.H.; McManus, D.D.; Goldberg, R.J.; Allen, L.A.; Hsu, G.; Sung, S.H.; Magid, D.J.; Go, A.S. Chronic kidney disease and outcomes in heart failure with preserved versus reduced ejection fraction: The Cardiovascular Research Network PRESERVE Study. Circ. Cardiovasc. Qual. Outcomes. 2013, 6, 333-342. [CrossRef]

18. Streng, K.W.; Nauta, J.F.; Hillege, H.L.; Anker, S.D.; Cleland, J.G.; Dickstein, K.; Filippatos, G.; Lang, C.C.; Metra, M.; Ng, L.L.; et al. Non-cardiac comorbidities in heart failure with reduced, mid-range and preserved ejection fraction. Int. J. Cardiol. 2018, 271, 132-139. [CrossRef]

19. Chen, G.Y.; Nunez, G. Sterile inflammation: Sensing and reacting to damage. Nat. Rev. Immunol. 2010, 10, 826-837. [CrossRef]

20. Yajima, T. Viral myocarditis: Potential defense mechanisms within the cardiomyocyte against virus infection. Future Microbiol 2011, 6, 551-566. [CrossRef] 
21. Pollack, A.; Kontorovich, A.R.; Fuster, V.; Dec, G.W. Viral myocarditis-diagnosis, treatment options, and current controversies. Nat. Rev. Cardiol. 2015, 12, 670-680. [CrossRef] [PubMed]

22. Tromp, J.; Lim, S.L.; Tay, W.T.; Teng, T.K.; Chandramouli, C.; Ouwerkerk, W.; Wander, G.S.; Sawhney, J.P.S.; Yap, J.; MacDonald, M.R.; et al. Microvascular Disease in Patients With Diabetes With Heart Failure and Reduced Ejection Versus Preserved Ejection Fraction. Diabetes Care 2019, 42, 1792-1799. [CrossRef] [PubMed]

23. Mohammed, S.F.; Hussain, S.; Mirzoyev, S.A.; Edwards, W.D.; Maleszewski, J.J.; Redfield, M.M. Coronary microvascular rarefaction and myocardial fibrosis in heart failure with preserved ejection fraction. Circulation 2015, 131, 550-559. [CrossRef] [PubMed]

24. Seferovic, P.M.; Paulus, W.J. Clinical diabetic cardiomyopathy: A two-faced disease with restrictive and dilated phenotypes. Eur. Heart J. 2015, 36, 1718-1727. [CrossRef]

25. Franssen, C.; Chen, S.; Unger, A.; Korkmaz, H.I.; De Keulenaer, G.W.; Tschope, C.; Leite-Moreira, A.F.; Musters, R.; Niessen, H.W.; Linke, W.A.; et al. Myocardial Microvascular Inflammatory Endothelial Activation in Heart Failure With Preserved Ejection Fraction. JACC Heart Fail 2016, 4, 312-324. [CrossRef]

26. Janicki, J.S.; Brower, G.L.; Gardner, J.D.; Chancey, A.L.; Stewart, J.A., Jr. The dynamic interaction between matrix metalloproteinase activity and adverse myocardial remodeling. Heart Fail Rev. 2004, 9, 33-42. [CrossRef]

27. Gonzalez, A.; Ravassa, S.; Beaumont, J.; Lopez, B.; Diez, J. New targets to treat the structural remodeling of the myocardium. J. Am. Coll. Cardiol. 2011, 58, 1833-1843. [CrossRef]

28. Gurusamy, N.; Das, D.K. Autophagy, redox signaling, and ventricular remodeling. Antioxid Redox Signal 2009, 11, 1975-1988. [CrossRef]

29. Tsutsui, H.; Kinugawa, S.; Matsushima, S. Oxidative stress and heart failure. Am. J. Physiol. Heart Circ. Physiol. 2011, 301, H2181-H2190. [CrossRef]

30. Penn, M.S. The role of leukocyte-generated oxidants in left ventricular remodeling. Am. J. Cardiol. 2008, 101, 30D-33D. [CrossRef]

31. Zile, M.R.; Gaasch, W.H.; Carroll, J.D.; Feldman, M.D.; Aurigemma, G.P.; Schaer, G.L.; Ghali, J.K.; Liebson, P.R. Heart failure with a normal ejection fraction: Is measurement of diastolic function necessary to make the diagnosis of diastolic heart failure? Circulation 2001, 104, 779-782. [CrossRef] [PubMed]

32. Zile, M.R.; Gottdiener, J.S.; Hetzel, S.J.; McMurray, J.J.; Komajda, M.; McKelvie, R.; Baicu, C.F.; Massie, B.M.; Carson, P.E.; Investigators, I.P. Prevalence and significance of alterations in cardiac structure and function in patients with heart failure and a preserved ejection fraction. Circulation 2011, 124, 2491-2501. [CrossRef] [PubMed]

33. Niessner, A.; Hohensinner, P.J.; Rychli, K.; Neuhold, S.; Zorn, G.; Richter, B.; Hulsmann, M.; Berger, R.; Mortl, D.; Huber, K.; et al. Prognostic value of apoptosis markers in advanced heart failure patients. Eur. Heart J. 2009, 30, 789-796. [CrossRef] [PubMed]

34. Jiang, L.; Huang, Y.; Hunyor, S.; dos Remedios, C.G. Cardiomyocyte apoptosis is associated with increased wall stress in chronic failing left ventricle. Eur. Heart J 2003, 24, 742-751. [CrossRef]

35. Xu, R.Y.; Zhu, X.F.; Yang, Y.; Ye, P. High-sensitive cardiac troponin T. J. Geriatr. Cardiol. 2013, 10, $102-109$. [CrossRef]

36. Dorn, G.W., 2nd. Apoptotic and non-apoptotic programmed cardiomyocyte death in ventricular remodelling. Cardiovasc. Res. 2009, 81, 465-473. [CrossRef]

37. Brouwers, F.P.; de Boer, R.A.; van der Harst, P.; Voors, A.A.; Gansevoort, R.T.; Bakker, S.J.; Hillege, H.L.; van Veldhuisen, D.J.; van Gilst, W.H. Incidence and epidemiology of new onset heart failure with preserved vs. reduced ejection fraction in a community-based cohort: 11-year follow-up of PREVEND. Eur. Heart J. 2013, 34, 1424-1431. [CrossRef]

38. Dai, Z.; Aoki, T.; Fukumoto, Y.; Shimokawa, H. Coronary perivascular fibrosis is associated with impairment of coronary blood flow in patients with non-ischemic heart failure. J. Cardiol. 2012, 60, 416-421. [CrossRef]

39. Roy, C.; Slimani, A.; de Meester, C.; Amzulescu, M.; Pasquet, A.; Vancraeynest, D.; Beauloye, C.; Vanoverschelde, J.L.; Gerber, B.L.; Pouleur, A.C. Associations and prognostic significance of diffuse myocardial fibrosis by cardiovascular magnetic resonance in heart failure with preserved ejection fraction. J. Cardiovasc. Magn. Reson. 2018, 20, 55. [CrossRef]

40. Kasner, M.; Westermann, D.; Lopez, B.; Gaub, R.; Escher, F.; Kuhl, U.; Schultheiss, H.P.; Tschope, C. Diastolic tissue Doppler indexes correlate with the degree of collagen expression and cross-linking in heart failure and normal ejection fraction. J. Am. Coll. Cardiol. 2011, 57, 977-985. [CrossRef] 
41. Aoki, T.; Fukumoto, Y.; Sugimura, K.; Oikawa, M.; Satoh, K.; Nakano, M.; Nakayama, M.; Shimokawa, H. Prognostic impact of myocardial interstitial fibrosis in non-ischemic heart failure. -Comparison between preserved and reduced ejection fraction heart failure. Circ J 2011, 75, 2605-2613. [CrossRef] [PubMed]

42. Forte, E.; Furtado, M.B.; Rosenthal, N. The interstitium in cardiac repair: Role of the immune-stromal cell interplay. Nat. Rev. Cardiol. 2018, 15, 601-616. [CrossRef] [PubMed]

43. Bielecka-Dabrowa, A.; Sakowicz, A.; Misztal, M.; von Haehling, S.; Ahmed, A.; Pietrucha, T.; Rysz, J.; Banach, M. Differences in biochemical and genetic biomarkers in patients with heart failure of various etiologies. Int. J. Cardiol. 2016, 221, 1073-1080. [CrossRef]

44. Collier, P.; Watson, C.J.; Voon, V.; Phelan, D.; Jan, A.; Mak, G.; Martos, R.; Baugh, J.A.; Ledwidge, M.T.; McDonald, K.M. Can emerging biomarkers of myocardial remodelling identify asymptomatic hypertensive patients at risk for diastolic dysfunction and diastolic heart failure? Eur. J. Heart Fail 2011, 13, 1087-1095. [CrossRef] [PubMed]

45. Boyle, A.J.; Yeghiazarians, Y.; Shih, H.; Hwang, J.; Ye, J.; Sievers, R.; Zheng, D.; Palasubramaniam, J.; Palasubramaniam, D.; Karschimkus, C.; et al. Myocardial production and release of MCP-1 and SDF-1 following myocardial infarction: Differences between mice and man. J. Transl. Med. 2011, 9, 150. [CrossRef] [PubMed]

46. Kobayashi, M.; Nakamura, K.; Kusano, K.F.; Nakamura, Y.; Ohta-Ogo, K.; Nagase, S.; Sakuragi, S.; Ohe, T. Expression of monocyte chemoattractant protein-1 in idiopathic dilated cardiomyopathy. Int. J. Cardiol. 2008, 126, 427-429. [CrossRef] [PubMed]

47. Broder, M.I.; Cohn, J.N. Evolution of abnormalities in left ventricular function after acute myocardial infarction. Circulation 1972, 46, 731-743. [CrossRef]

48. Diamond, G.; Forrester, J.S. Effect of coronary artery disease and acute myocardial infarction on left ventricular compliance in man. Circulation 1972, 45, 11-19. [CrossRef]

49. Russell, R.O., Jr.; Hunt, D.; Rackley, C.E. Left ventricular hemodynamics in anterior and inferior myocardial infarction. Am. J. Cardiol. 1973, 32, 8-16. [CrossRef]

50. Aoyagi, T.; Pouleur, H.; Van Eyll, C.; Rousseau, M.F.; Mirsky, I. Wall motion asynchrony is a major determinant of impaired left ventricular filling in patients with healed myocardial infarction. Am. J. Cardiol. 1993, 72, 268-272. [CrossRef]

51. Smith, M.; Ratshin, R.A.; Harrell, F.E., Jr.; Russell, R.O., Jr.; Rackley, C.E. Early sequential changes in left ventricular dimensions and filling pressure in patients after myocardial infarction. Am. J. Cardiol. 1974, 33, 363-369. [CrossRef]

52. Bertrand, M.E.; Rousseau, M.F.; Lefebvre, J.M.; Lablanche, J.M.; Asseman, P.H.; Carre, A.G.; Lekieffre, J.P. Left ventricular compliance in acute transmural myocardial infarction in man. Eur. J. Cardiol. 1978, 7, 179-193.

53. Paulus, W.J.; Dal Canto, E. Distinct Myocardial Targets for Diabetes Therapy in Heart Failure With Preserved or Reduced Ejection Fraction. JACC Heart Fail 2018, 6, 1-7. [CrossRef] [PubMed]

54. van Heerebeek, L.; Borbely, A.; Niessen, H.W.; Bronzwaer, J.G.; van der Velden, J.; Stienen, G.J.; Linke, W.A.; Laarman, G.J.; Paulus, W.J. Myocardial structure and function differ in systolic and diastolic heart failure. Circulation 2006, 113, 1966-1973. [CrossRef] [PubMed]

55. Roe, A.T.; Aronsen, J.M.; Skardal, K.; Hamdani, N.; Linke, W.A.; Danielsen, H.E.; Sejersted, O.M.; Sjaastad, I.; Louch, W.E. Increased passive stiffness promotes diastolic dysfunction despite improved Ca2+ handling during left ventricular concentric hypertrophy. Cardiovasc. Res. 2017, 113, 1161-1172. [CrossRef] [PubMed]

56. Nagueh, S.F.; Shah, G.; Wu, Y.; Torre-Amione, G.; King, N.M.; Lahmers, S.; Witt, C.C.; Becker, K.; Labeit, S.; Granzier, H.L. Altered titin expression, myocardial stiffness, and left ventricular function in patients with dilated cardiomyopathy. Circulation 2004, 110, 155-162. [CrossRef] [PubMed]

57. Franssen, C.; Kole, J.; Musters, R.; Hamdani, N.; Paulus, W.J. alpha-B Crystallin Reverses High Diastolic Stiffness of Failing Human Cardiomyocytes. Circ Heart Fail 2017, 10, e003626. [CrossRef]

58. Verdonschot, J.A.J.; Hazebroek, M.R.; Derks, K.W.J.; Barandiaran Aizpurua, A.; Merken, J.J.; Wang, P.; Bierau, J.; van den Wijngaard, A.; Schalla, S.M.; Abdul Hamid, M.A.; et al. Titin cardiomyopathy leads to altered mitochondrial energetics, increased fibrosis and long-term life-threatening arrhythmias. Eur. Heart J. 2018, 39, 864-873. [CrossRef]

59. Ali, M.A.; Cho, W.J.; Hudson, B.; Kassiri, Z.; Granzier, H.; Schulz, R. Titin is a target of matrix metalloproteinase-2: Implications in myocardial ischemia/reperfusion injury. Circulation 2010, 122, $2039-2047$. [CrossRef] 
60. Pieske, B.; Maier, L.S.; Piacentino, V., 3rd; Weisser, J.; Hasenfuss, G.; Houser, S. Rate dependence of [Na+]i and contractility in nonfailing and failing human myocardium. Circulation 2002, 106, 447-453. [CrossRef]

61. Limas, C.J.; Olivari, M.T.; Goldenberg, I.F.; Levine, T.B.; Benditt, D.G.; Simon, A. Calcium uptake by cardiac sarcoplasmic reticulum in human dilated cardiomyopathy. Cardiovasc. Res. 1987, 21, 601-605. [CrossRef]

62. Hasenfuss, G.; Reinecke, H.; Studer, R.; Meyer, M.; Pieske, B.; Holtz, J.; Holubarsch, C.; Posival, H.; Just, H.; Drexler, H. Relation between myocardial function and expression of sarcoplasmic reticulum Ca(2+)-ATPase in failing and nonfailing human myocardium. Circ. Res. 1994, 75, 434-442. [CrossRef] [PubMed]

63. Mercadier, J.J.; Lompre, A.M.; Duc, P.; Boheler, K.R.; Fraysse, J.B.; Wisnewsky, C.; Allen, P.D.; Komajda, M.; Schwartz, K. Altered sarcoplasmic reticulum Ca2(+)-ATPase gene expression in the human ventricle during end-stage heart failure. J. Clin. Investig. 1990, 85, 305-309. [CrossRef] [PubMed]

64. Meyer, M.; Schillinger, W.; Pieske, B.; Holubarsch, C.; Heilmann, C.; Posival, H.; Kuwajima, G.; Mikoshiba, K.; Just, H.; Hasenfuss, G.; et al. Alterations of sarcoplasmic reticulum proteins in failing human dilated cardiomyopathy. Circulation 1995, 92, 778-784. [CrossRef] [PubMed]

65. Schwinger, R.H.; Munch, G.; Bolck, B.; Karczewski, P.; Krause, E.G.; Erdmann, E. Reduced Ca(2+)-sensitivity of SERCA 2a in failing human myocardium due to reduced serin-16 phospholamban phosphorylation. J. Mol. Cell. Cardiol. 1999, 31, 479-491. [CrossRef]

66. Westermann, D.; Kasner, M.; Steendijk, P.; Spillmann, F.; Riad, A.; Weitmann, K.; Hoffmann, W.; Poller, W.; Pauschinger, M.; Schultheiss, H.P.; et al. Role of left ventricular stiffness in heart failure with normal ejection fraction. Circulation 2008, 117, 2051-2060. [CrossRef]

67. Kruger, M.; Babicz, K.; von Frieling-Salewsky, M.; Linke, W.A. Insulin signaling regulates cardiac titin properties in heart development and diabetic cardiomyopathy. J. Mol. Cell. Cardiol. 2010, 48, 910-916. [CrossRef]

68. Warren, C.M.; Jordan, M.C.; Roos, K.P.; Krzesinski, P.R.; Greaser, M.L. Titin isoform expression in normal and hypertensive myocardium. Cardiovasc. Res. 2003, 59, 86-94. [CrossRef]

69. Hamdani, N.; Bishu, K.G.; von Frieling-Salewsky, M.; Redfield, M.M.; Linke, W.A. Deranged myofilament phosphorylation and function in experimental heart failure with preserved ejection fraction. Cardiovasc. Res. 2013, 97, 464-471. [CrossRef]

70. Zhu, C.; Odhiambo, J.F.; Ghnesis, A.; Ford, S.P.; Nathanielsz, P.W.; Ren, J.F.; Guo, W. Maternal Obesity (OB) Increases the Stiffer, Shorter Titin Isoform in the Maternal and Fetal Heart. Reprod. Sci. 2016, 23, 146-147.

71. Hopf, A.E.; Andresen, C.; Kotter, S.; Isic, M.; Ulrich, K.; Sahin, S.; Bongardt, S.; Roll, W.; Drove, F.; Scheerer, N.; et al. Diabetes-Induced Cardiomyocyte Passive Stiffening Is Caused by Impaired Insulin-Dependent Titin Modification and Can Be Modulated by Neuregulin-1. Circ. Res. 2018, 123, 342-355. [CrossRef] [PubMed]

72. Borbely, A.; Falcao-Pires, I.; van Heerebeek, L.; Hamdani, N.; Edes, I.; Gavina, C.; Leite-Moreira, A.F.; Bronzwaer, J.G.; Papp, Z.; van der Velden, J.; et al. Hypophosphorylation of the Stiff N2B titin isoform raises cardiomyocyte resting tension in failing human myocardium. Circ. Res. 2009, 104, 780-786. [CrossRef] [PubMed]

73. Hamdani, N.; Franssen, C.; Lourenco, A.; Falcao-Pires, I.; Fontoura, D.; Leite, S.; Plettig, L.; Lopez, B.; Ottenheijm, C.A.; Becher, P.M.; et al. Myocardial titin hypophosphorylation importantly contributes to heart failure with preserved ejection fraction in a rat metabolic risk model. Circ. Heart Fail 2013, 6, 1239-1249. [CrossRef] [PubMed]

74. Zile, M.R.; Baicu, C.F.; Ikonomidis, J.S.; Stroud, R.E.; Nietert, P.J.; Bradshaw, A.D.; Slater, R.; Palmer, B.M.; Van Buren, P.; Meyer, M.; et al. Myocardial stiffness in patients with heart failure and a preserved ejection fraction: Contributions of collagen and titin. Circulation 2015, 131, 1247-1259. [CrossRef] [PubMed]

75. Runte, K.E.; Bell, S.P.; Selby, D.E.; Haussler, T.N.; Ashikaga, T.; LeWinter, M.M.; Palmer, B.M.; Meyer, M. Relaxation and the Role of Calcium in Isolated Contracting Myocardium From Patients With Hypertensive Heart Disease and Heart Failure With Preserved Ejection Fraction. Circ. Heart Fail 2017, 10. [CrossRef] [PubMed]

76. Van Linthout, S.; Tschope, C. Inflammation - Cause or Consequence of Heart Failure or Both? Curr. Heart Fail Rep. 2017, 14, 251-265. [CrossRef] [PubMed]

77. Bezbradica, J.S.; Coll, R.C.; Schroder, K. Sterile signals generate weaker and delayed macrophage NLRP3 inflammasome responses relative to microbial signals. Cell Mol. Immunol. 2017, 14, 118-126. [CrossRef]

78. Nahrendorf, M.; Swirski, F.K. Innate immune cells in ischaemic heart disease: Does myocardial infarction beget myocardial infarction? Eur. Heart J. 2016, 37, 868-872. [CrossRef] 
79. Katayama, Y.; Battista, M.; Kao, W.M.; Hidalgo, A.; Peired, A.J.; Thomas, S.A.; Frenette, P.S. Signals from the sympathetic nervous system regulate hematopoietic stem cell egress from bone marrow. Cell 2006, 124, 407-421. [CrossRef]

80. Nunez, J.; Nunez, E.; Bodi, V.; Sanchis, J.; Minana, G.; Mainar, L.; Santas, E.; Merlos, P.; Rumiz, E.; Darmofal, H.; et al. Usefulness of the neutrophil to lymphocyte ratio in predicting long-term mortality in ST segment elevation myocardial infarction. Am. J. Cardiol. 2008, 101, 747-752. [CrossRef]

81. Dutta, P.; Nahrendorf, M. Monocytes in myocardial infarction. Arter. Thromb. Vasc. Biol. 2015, 35, $1066-1070$. [CrossRef] [PubMed]

82. Swirski, F.K.; Nahrendorf, M.; Etzrodt, M.; Wildgruber, M.; Cortez-Retamozo, V.; Panizzi, P.; Figueiredo, J.L.; Kohler, R.H.; Chudnovskiy, A.; Waterman, P.; et al. Identification of splenic reservoir monocytes and their deployment to inflammatory sites. Science 2009, 325, 612-616. [CrossRef] [PubMed]

83. van der Laan, A.M.; Nahrendorf, M.; Piek, J.J. Republished: Healing and adverse remodelling after acute myocardial infarction: Role of the cellular immune response. Postgrad Med. J. 2013, 89, 52-58. [CrossRef] [PubMed]

84. Lindsey, M.L.; Mann, D.L.; Entman, M.L.; Spinale, F.G. Extracellular matrix remodeling following myocardial injury. Ann. Med. 2003, 35, 316-326. [CrossRef]

85. Zouggari, Y.; Ait-Oufella, H.; Bonnin, P.; Simon, T.; Sage, A.P.; Guerin, C.; Vilar, J.; Caligiuri, G.; Tsiantoulas, D.; Laurans, L.; et al. B lymphocytes trigger monocyte mobilization and impair heart function after acute myocardial infarction. Nat. Med. 2013, 19, 1273-1280. [CrossRef]

86. Tang, T.T.; Yuan, J.; Zhu, Z.F.; Zhang, W.C.; Xiao, H.; Xia, N.; Yan, X.X.; Nie, S.F.; Liu, J.; Zhou, S.F.; et al. Regulatory T cells ameliorate cardiac remodeling after myocardial infarction. Basic Res. Cardiol. 2012, 107, 232. [CrossRef]

87. Amin, M.N.; Mosa, A.A.; El-Shishtawy, M.M. Clinical study of advanced glycation end products in egyptian diabetic obese and non-obese patients. Int. J. Biomed Sci. 2011, 7, 191-200.

88. Beyan, H.; Riese, H.; Hawa, M.I.; Beretta, G.; Davidson, H.W.; Hutton, J.C.; Burger, H.; Schlosser, M.; Snieder, H.; Boehm, B.O.; et al. Glycotoxin and autoantibodies are additive environmentally determined predictors of type 1 diabetes: A twin and population study. Diabetes 2012, 61, 1192-1198. [CrossRef]

89. Chao, P.C.; Huang, C.N.; Hsu, C.C.; Yin, M.C.; Guo, Y.R. Association of dietary AGEs with circulating AGEs, glycated LDL, IL-1alpha and MCP-1 levels in type 2 diabetic patients. Eur. J. Nutr. 2010, 49, 429-434. [CrossRef]

90. Miyata, T.; Inagi, R.; Iida, Y.; Sato, M.; Yamada, N.; Oda, O.; Maeda, K.; Seo, H. Involvement of beta 2-microglobulin modified with advanced glycation end products in the pathogenesis of hemodialysis-associated amyloidosis. Induction of human monocyte chemotaxis and macrophage secretion of tumor necrosis factor-alpha and interleukin-1. J. Clin. Investig. 1994, 93, 521-528. [CrossRef]

91. Kalogeropoulos, A.; Georgiopoulou, V.; Psaty, B.M.; Rodondi, N.; Smith, A.L.; Harrison, D.G.; Liu, Y.; Hoffmann, U.; Bauer, D.C.; Newman, A.B.; et al. Inflammatory markers and incident heart failure risk in older adults: The Health ABC (Health, Aging, and Body Composition) study. J. Am. Coll Cardiol. 2010, 55, 2129-2137. [CrossRef] [PubMed]

92. DuBrock, H.M.; AbouEzzeddine, O.F.; Redfield, M.M. High-sensitivity C-reactive protein in heart failure with preserved ejection fraction. PLoS ONE 2018, 13, e0201836. [CrossRef] [PubMed]

93. Hulsmans, M.; Sager, H.B.; Roh, J.D.; Valero-Munoz, M.; Houstis, N.E.; Iwamoto, Y.; Sun, Y.; Wilson, R.M.; Wojtkiewicz, G.; Tricot, B.; et al. Cardiac macrophages promote diastolic dysfunction. J. Exp. Med. 2018, 215, 423-440. [CrossRef] [PubMed]

94. Glezeva, N.; Voon, V.; Watson, C.; Horgan, S.; McDonald, K.; Ledwidge, M.; Baugh, J. Exaggerated inflammation and monocytosis associate with diastolic dysfunction in heart failure with preserved ejection fraction: Evidence of M2 macrophage activation in disease pathogenesis. J. Card Fail 2015, 21, 167-177. [CrossRef] [PubMed]

95. Haraldsen, G.; Kvale, D.; Lien, B.; Farstad, I.N.; Brandtzaeg, P. Cytokine-regulated expression of E-selectin, intercellular adhesion molecule-1 (ICAM-1), and vascular cell adhesion molecule-1 (VCAM-1) in human microvascular endothelial cells. J. Immunol. 1996, 156, 2558-2565. [PubMed]

96. Bonfanti, R.; Furie, B.C.; Furie, B.; Wagner, D.D. PADGEM (GMP140) is a component of Weibel-Palade bodies of human endothelial cells. Blood 1989, 73, 1109-1112. [CrossRef] [PubMed] 
97. Cabandugama, P.K.; Gardner, M.J.; Sowers, J.R. The Renin Angiotensin Aldosterone System in Obesity and Hypertension: Roles in the Cardiorenal Metabolic Syndrome. Med. Clin. North. Am. 2017, 101, 129-137. [CrossRef]

98. Pastore, L.; Tessitore, A.; Martinotti, S.; Toniato, E.; Alesse, E.; Bravi, M.C.; Ferri, C.; Desideri, G.; Gulino, A.; Santucci, A. Angiotensin II stimulates intercellular adhesion molecule-1 (ICAM-1) expression by human vascular endothelial cells and increases soluble ICAM-1 release in vivo. Circulation 1999, 100, 1646-1652. [CrossRef]

99. Grafe, M.; Auch-Schwelk, W.; Zakrzewicz, A.; Regitz-Zagrosek, V.; Bartsch, P.; Graf, K.; Loebe, M.; Gaehtgens, P.; Fleck, E. Angiotensin II-induced leukocyte adhesion on human coronary endothelial cells is mediated by E-selectin. Circ. Res. 1997, 81, 804-811. [CrossRef]

100. Tummala, P.E.; Chen, X.L.; Sundell, C.L.; Laursen, J.B.; Hammes, C.P.; Alexander, R.W.; Harrison, D.G.; Medford, R.M. Angiotensin II induces vascular cell adhesion molecule-1 expression in rat vasculature: A potential link between the renin-angiotensin system and atherosclerosis. Circulation 1999, 100, 1223-1229. [CrossRef]

101. Bierhaus, A.; Humpert, P.M.; Morcos, M.; Wendt, T.; Chavakis, T.; Arnold, B.; Stern, D.M.; Nawroth, P.P. Understanding RAGE, the receptor for advanced glycation end products. J. Mol. Med. (Berl) 2005, 83, 876-886. [CrossRef] [PubMed]

102. Westermann, D.; Lindner, D.; Kasner, M.; Zietsch, C.; Savvatis, K.; Escher, F.; von Schlippenbach, J.; Skurk, C.; Steendijk, P.; Riad, A.; et al. Cardiac inflammation contributes to changes in the extracellular matrix in patients with heart failure and normal ejection fraction. Circ. Heart Fail 2011, 4, 44-52. [CrossRef] [PubMed]

103. Pinto, A.R.; Ilinykh, A.; Ivey, M.J.; Kuwabara, J.T.; D’Antoni, M.L.; Debuque, R.; Chandran, A.; Wang, L.; Arora, K.; Rosenthal, N.A.; et al. Revisiting Cardiac Cellular Composition. Circ. Res. 2016, 118, 400-409. [CrossRef] [PubMed]

104. Widlansky, M.E.; Gokce, N.; Keaney, J.F., Jr.; Vita, J.A. The clinical implications of endothelial dysfunction. J. Am. Coll. Cardiol. 2003, 42, 1149-1160. [CrossRef]

105. Katz, S.D.; Hryniewicz, K.; Hriljac, I.; Balidemaj, K.; Dimayuga, C.; Hudaihed, A.; Yasskiy, A. Vascular endothelial dysfunction and mortality risk in patients with chronic heart failure. Circulation 2005, 111, 310-314. [CrossRef]

106. Alem, M.M. Endothelial Dysfunction in Chronic Heart Failure: Assessment, Findings, Significance, and Potential Therapeutic Targets. Int. J. Mol. Sci. 2019, 20. [CrossRef]

107. Fischer, D.; Rossa, S.; Landmesser, U.; Spiekermann, S.; Engberding, N.; Hornig, B.; Drexler, H. Endothelial dysfunction in patients with chronic heart failure is independently associated with increased incidence of hospitalization, cardiac transplantation, or death. Eur. Heart J. 2005, 26, 65-69. [CrossRef]

108. Katz, S.D.; Biasucci, L.; Sabba, C.; Strom, J.A.; Jondeau, G.; Galvao, M.; Solomon, S.; Nikolic, S.D.; Forman, R.; LeJemtel, T.H. Impaired endothelium-mediated vasodilation in the peripheral vasculature of patients with congestive heart failure. J. Am. Coll. Cardiol. 1992, 19, 918-925. [CrossRef]

109. Kubo, S.H.; Rector, T.S.; Bank, A.J.; Williams, R.E.; Heifetz, S.M. Endothelium-dependent vasodilation is attenuated in patients with heart failure. Circulation 1991, 84, 1589-1596. [CrossRef]

110. Witman, M.A.; Fjeldstad, A.S.; McDaniel, J.; Ives, S.J.; Zhao, J.; Barrett-O'Keefe, Z.; Nativi, J.N.; Stehlik, J.; Wray, D.W.; Richardson, R.S. Vascular function and the role of oxidative stress in heart failure, heart transplant, and beyond. Hypertension 2012, 60, 659-668. [CrossRef]

111. Treasure, C.B.; Vita, J.A.; Cox, D.A.; Fish, R.D.; Gordon, J.B.; Mudge, G.H.; Colucci, W.S.; Sutton, M.G.; Selwyn, A.P.; Alexander, R.W.; et al. Endothelium-dependent dilation of the coronary microvasculature is impaired in dilated cardiomyopathy. Circulation 1990, 81, 772-779. [CrossRef] [PubMed]

112. Torre-Amione, G.; Kapadia, S.; Benedict, C.; Oral, H.; Young, J.B.; Mann, D.L. Proinflammatory cytokine levels in patients with depressed left ventricular ejection fraction: A report from the Studies of Left Ventricular Dysfunction (SOLVD). J. Am. Coll. Cardiol. 1996, 27, 1201-1206. [CrossRef]

113. Marti, C.N.; Gheorghiade, M.; Kalogeropoulos, A.P.; Georgiopoulou, V.V.; Quyyumi, A.A.; Butler, J. Endothelial dysfunction, arterial stiffness, and heart failure. J. Am. Coll. Cardiol. 2012, 60, 1455-1469. [CrossRef] [PubMed]

114. Hare, J.M. Nitroso-redox balance in the cardiovascular system. N. Engl. J. Med. 2004, 351, $2112-2114$. [CrossRef] [PubMed] 
115. Karantalis, V.; Schulman, I.H.; Hare, J.M. Nitroso-redox imbalance affects cardiac structure and function. J. Am. Coll. Cardiol. 2013, 61, 933-935. [CrossRef] [PubMed]

116. Taddei, S.; Virdis, A.; Ghiadoni, L.; Mattei, P.; Sudano, I.; Bernini, G.; Pinto, S.; Salvetti, A. Menopause is associated with endothelial dysfunction in women. Hypertension 1996, 28, 576-582. [CrossRef]

117. Kawano, H.; Motoyama, T.; Kugiyama, K.; Hirashima, O.; Ohgushi, M.; Yoshimura, M.; Ogawa, H.; Okumura, K.; Yasue, H. Menstrual cyclic variation of endothelium-dependent vasodilation of the brachial artery: Possible role of estrogen and nitric oxide. Proc. Assoc. Am. Physicians 1996, 108, 473-480.

118. David, F.L.; Carvalho, M.H.; Cobra, A.L.; Nigro, D.; Fortes, Z.B.; Reboucas, N.A.; Tostes, R.C. Ovarian hormones modulate endothelin-1 vascular reactivity and mRNA expression in DOCA-salt hypertensive rats. Hypertension 2001, 38, 692-696. [CrossRef]

119. Nevzati, E.; Shafighi, M.; Bakhtian, K.D.; Treiber, H.; Fandino, J.; Fathi, A.R. Estrogen induces nitric oxide production via nitric oxide synthase activation in endothelial cells. Acta Neurochir. Suppl. 2015, 120, 141-145. [CrossRef]

120. Pedersen, S.H.; Nielsen, L.B.; Mortensen, A.; Nilas, L.; Ottesen, B. Progestins oppose the effects of estradiol on the endothelin-1 receptor type B in coronary arteries from ovariectomized hyperlipidemic rabbits. Menopause 2008, 15, 503-510. [CrossRef]

121. Du, X.J.; Riemersma, R.A.; Dart, A.M. Cardiovascular protection by oestrogen is partly mediated through modulation of autonomic nervous function. Cardiovasc. Res. 1995, 30, 161-165. [CrossRef]

122. Matthews, K.A.; Crawford, S.L.; Chae, C.U.; Everson-Rose, S.A.; Sowers, M.F.; Sternfeld, B.; Sutton-Tyrrell, K. Are changes in cardiovascular disease risk factors in midlife women due to chronological aging or to the menopausal transition? J. Am. Coll. Cardiol. 2009, 54, 2366-2373. [CrossRef] [PubMed]

123. Sivritas, D.; Becher, M.U.; Ebrahimian, T.; Arfa, O.; Rapp, S.; Bohner, A.; Mueller, C.F.; Umemura, T.; Wassmann, S.; Nickenig, G.; et al. Antiproliferative effect of estrogen in vascular smooth muscle cells is mediated by Kruppel-like factor-4 and manganese superoxide dismutase. Basic Res. Cardiol. 2011, 106, 563-575. [CrossRef] [PubMed]

124. Gros, R.; Hussain, Y.; Chorazyczewski, J.; Pickering, J.G.; Ding, Q.; Feldman, R.D. Extent of Vascular Remodeling Is Dependent on the Balance Between Estrogen Receptor alpha and G-Protein-Coupled Estrogen Receptor. Hypertension 2016, 68, 1225-1235. [CrossRef] [PubMed]

125. Song, J.Y.; Kim, M.J.; Jo, H.H.; Hwang, S.J.; Chae, B.; Chung, J.E.; Kwon, D.J.; Lew, Y.O.; Lim, Y.T.; Kim, J.H.; et al. Antioxidant effect of estrogen on bovine aortic endothelial cells. J. Steroid Biochem Mol. Biol. 2009, 117, 74-80. [CrossRef] [PubMed]

126. Jankowska, E.A.; Rozentryt, P.; Ponikowska, B.; Hartmann, O.; Kustrzycka-Kratochwil, D.; Reczuch, K.; Nowak, J.; Borodulin-Nadzieja, L.; Polonski, L.; Banasiak, W.; et al. Circulating estradiol and mortality in men with systolic chronic heart failure. JAMA 2009, 301, 1892-1901. [CrossRef]

127. Xu, Y.; Arenas, I.A.; Armstrong, S.J.; Plahta, W.C.; Xu, H.; Davidge, S.T. Estrogen improves cardiac recovery after ischemia/reperfusion by decreasing tumor necrosis factor-alpha. Cardiovasc. Res. 2006, 69, 836-844. [CrossRef]

128. Alecrin, I.N.; Aldrighi, J.M.; Caldas, M.A.; Gebara, O.C.; Lopes, N.H.; Ramires, J.A. Acute and chronic effects of oestradiol on left ventricular diastolic function in hypertensive postmenopausal women with left ventricular diastolic dysfunction. Heart 2004, 90, 777-781. [CrossRef]

129. Dhot, J.; Prat, V.; Stevant, D.; Ferron, M.; Aillerie, V.; Erraud, E.; Erfanian, M.; De Waard, M.; Rozec, B.; Trochu, J.; et al. Phytoestrogen: Protective effect in HFpEF through ageing? Arch. Cardiovasc. Dis. Suppl. 2019, 11, 226. [CrossRef]

130. van Heerebeek, L.; Hamdani, N.; Falcao-Pires, I.; Leite-Moreira, A.F.; Begieneman, M.P.; Bronzwaer, J.G.; van der Velden, J.; Stienen, G.J.; Laarman, G.J.; Somsen, A.; et al. Low myocardial protein kinase G activity in heart failure with preserved ejection fraction. Circulation 2012, 126, 830-839. [CrossRef]

131. Faxen, U.L.; Hage, C.; Benson, L.; Zabarovskaja, S.; Andreasson, A.; Donal, E.; Daubert, J.C.; Linde, C.; Brismar, K.; Lund, L.H. HFpEF and HFrEF Display Different Phenotypes as Assessed by IGF-1 and IGFBP-1. J. Card Fail 2017, 23, 293-303. [CrossRef] [PubMed]

132. Vinciguerra, M.; Santini, M.P.; Claycomb, W.C.; Ladurner, A.G.; Rosenthal, N. Local IGF-1 isoform protects cardiomyocytes from hypertrophic and oxidative stresses via SirT1 activity. Aging 2009, 2, 43-62. [CrossRef] [PubMed] 
133. Kostin, S.; Pool, L.; Elsasser, A.; Hein, S.; Drexler, H.C.; Arnon, E.; Hayakawa, Y.; Zimmermann, R.; Bauer, E.; Klovekorn, W.P.; et al. Myocytes die by multiple mechanisms in failing human hearts. Circ. Res. 2003, 92, 715-724. [CrossRef] [PubMed]

134. Umansky, S.R.; Cuenco, G.M.; Khutzian, S.S.; Barr, P.J.; Tomei, L.D. Post-ischemic apoptotic death of rat neonatal cardiomyocytes. Cell Death Differ. 1995, 2, 235-241. [PubMed]

135. Cheng, W.; Li, B.; Kajstura, J.; Li, P.; Wolin, M.S.; Sonnenblick, E.H.; Hintze, T.H.; Olivetti, G.; Anversa, P. Stretch-induced programmed myocyte cell death. J. Clin. Investig. 1995, 96, 2247-2259. [CrossRef] [PubMed]

136. Hamblin, M.; Friedman, D.B.; Hill, S.; Caprioli, R.M.; Smith, H.M.; Hill, M.F. Alterations in the diabetic myocardial proteome coupled with increased myocardial oxidative stress underlies diabetic cardiomyopathy. J. Mol. Cell Cardiol. 2007, 42, 884-895. [CrossRef] [PubMed]

137. Fuentes-Antras, J.; Picatoste, B.; Ramirez, E.; Egido, J.; Tunon, J.; Lorenzo, O. Targeting metabolic disturbance in the diabetic heart. Cardiovasc Diabetol. 2015, 14, 17. [CrossRef]

138. Wei, J.; Nelson, M.D.; Szczepaniak, E.W.; Smith, L.; Mehta, P.K.; Thomson, L.E.; Berman, D.S.; Li, D.; Bairey Merz, C.N.; Szczepaniak, L.S. Myocardial steatosis as a possible mechanistic link between diastolic dysfunction and coronary microvascular dysfunction in women. Am. J. Physiol. Heart Circ. Physiol. 2016, 310, H14-H19. [CrossRef]

139. Sparagna, G.C.; Hickson-Bick, D.L.; Buja, L.M.; McMillin, J.B. A metabolic role for mitochondria in palmitate-induced cardiac myocyte apoptosis. Am. J. Physiol. Heart Circ. Physiol. 2000, 279, $2124-2132$. [CrossRef]

140. Yagyu, H.; Chen, G.; Yokoyama, M.; Hirata, K.; Augustus, A.; Kako, Y.; Seo, T.; Hu, Y.; Lutz, E.P.; Merkel, M.; et al. Lipoprotein lipase (LpL) on the surface of cardiomyocytes increases lipid uptake and produces a cardiomyopathy. J. Clin. Investig. 2003, 111, 419-426. [CrossRef]

141. Chiu, H.C.; Kovacs, A.; Ford, D.A.; Hsu, F.F.; Garcia, R.; Herrero, P.; Saffitz, J.E.; Schaffer, J.E. A novel mouse model of lipotoxic cardiomyopathy. J. Clin. Investig. 2001, 107, 813-822. [CrossRef] [PubMed]

142. Chiu, H.C.; Kovacs, A.; Blanton, R.M.; Han, X.; Courtois, M.; Weinheimer, C.J.; Yamada, K.A.; Brunet, S.; $\mathrm{Xu}, \mathrm{H}$.; Nerbonne, J.M.; et al. Transgenic expression of fatty acid transport protein 1 in the heart causes lipotoxic cardiomyopathy. Circ. Res. 2005, 96, 225-233. [CrossRef] [PubMed]

143. Corsetti, G.; Chen-Scarabelli, C.; Romano, C.; Pasini, E.; Dioguardi, F.S.; Onorati, F.; Knight, R.; Patel, H.; Saravolatz, L.; Faggian, G.; et al. Autophagy and Oncosis/Necroptosis Are Enhanced in Cardiomyocytes from Heart Failure Patients. Med. Sci. Monit. Basic Res. 2019, 25, 33-44. [CrossRef] [PubMed]

144. Wencker, D.; Chandra, M.; Nguyen, K.; Miao, W.; Garantziotis, S.; Factor, S.M.; Shirani, J.; Armstrong, R.C.; Kitsis, R.N. A mechanistic role for cardiac myocyte apoptosis in heart failure. J. Clin. Investig. 2003, 111, 1497-1504. [CrossRef]

145. Chaanine, A.H.; Kohlbrenner, E.; Gamb, S.I.; Guenzel, A.J.; Klaus, K.; Fayyaz, A.U.; Nair, K.S.; Hajjar, R.J.; Redfield, M.M. FOXO3a regulates BNIP3 and modulates mitochondrial calcium, dynamics, and function in cardiac stress. Am. J. Physiol. Heart Circ. Physiol. 2016, 311, H1540-H1559. [CrossRef]

146. Weber, K.T. Cardiac interstitium in health and disease: The fibrillar collagen network. J. Am. Coll. Cardiol. 1989, 13, 1637-1652. [CrossRef]

147. Baicu, C.F.; Stroud, J.D.; Livesay, V.A.; Hapke, E.; Holder, J.; Spinale, F.G.; Zile, M.R. Changes in extracellular collagen matrix alter myocardial systolic performance. Am. J. Physiol. Heart Circ. Physiol. 2003, 284, H122-H132. [CrossRef]

148. Wang, J.; Hoshijima, M.; Lam, J.; Zhou, Z.; Jokiel, A.; Dalton, N.D.; Hultenby, K.; Ruiz-Lozano, P.; Ross, J., Jr.; Tryggvason, K.; et al. Cardiomyopathy associated with microcirculation dysfunction in laminin alpha4 chain-deficient mice. J. Biol. Chem. 2006, 281, 213-220. [CrossRef]

149. Echegaray, K.; Andreu, I.; Lazkano, A.; Villanueva, I.; Saenz, A.; Elizalde, M.R.; Echeverria, T.; Lopez, B.; Garro, A.; Gonzalez, A.; et al. Role of Myocardial Collagen in Severe Aortic Stenosis With Preserved Ejection Fraction and Symptoms of Heart Failure. Rev. Esp. Cardiol. (Engl. Ed.) 2017, 70, 832-840. [CrossRef]

150. Fowlkes, V.; Clark, J.; Fix, C.; Law, B.A.; Morales, M.O.; Qiao, X.; Ako-Asare, K.; Goldsmith, J.G.; Carver, W.; Murray, D.B.; et al. Type II diabetes promotes a myofibroblast phenotype in cardiac fibroblasts. Life Sci. 2013, 92, 669-676. [CrossRef]

151. Willems, I.E.; Havenith, M.G.; De Mey, J.G.; Daemen, M.J. The alpha-smooth muscle actin-positive cells in healing human myocardial scars. Am. J. Pathol. 1994, 145, 868-875. [PubMed] 
152. Leslie, K.O.; Taatjes, D.J.; Schwarz, J.; vonTurkovich, M.; Low, R.B. Cardiac myofibroblasts express alpha smooth muscle actin during right ventricular pressure overload in the rabbit. Am. J. Pathol. 1991, 139, 207-216. [PubMed]

153. Szardien, S.; Nef, H.M.; Troidl, C.; Willmer, M.; Voss, S.; Liebetrau, C.; Hoffmann, J.; Rolf, A.; Rixe, J.; Elsasser, A.; et al. Bone marrow-derived cells contribute to cell turnover in aging murine hearts. Int. J. Mol. Med. 2012, 30, 283-287. [CrossRef] [PubMed]

154. Sato, Y.; Rifkin, D.B. Inhibition of endothelial cell movement by pericytes and smooth muscle cells: Activation of a latent transforming growth factor-beta 1-like molecule by plasmin during co-culture. J. Cell Biol. 1989, 109, 309-315. [CrossRef]

155. Yu, Q.; Stamenkovic, I. Cell surface-localized matrix metalloproteinase-9 proteolytically activates TGF-beta and promotes tumor invasion and angiogenesis. Genes Dev. 2000, 14, 163-176.

156. Crawford, S.E.; Stellmach, V.; Murphy-Ullrich, J.E.; Ribeiro, S.M.; Lawler, J.; Hynes, R.O.; Boivin, G.P.; Bouck, N. Thrombospondin-1 is a major activator of TGF-beta1 in vivo. Cell 1998, 93, 1159-1170. [CrossRef]

157. Asano, Y.; Ihn, H.; Yamane, K.; Jinnin, M.; Mimura, Y.; Tamaki, K. Involvement of alphavbeta5 integrin-mediated activation of latent transforming growth factor beta1 in autocrine transforming growth factor beta signaling in systemic sclerosis fibroblasts. Arthritis Rheum 2005, 52, 2897-2905. [CrossRef]

158. Morishita, T.; Uzui, H.; Mitsuke, Y.; Amaya, N.; Kaseno, K.; Ishida, K.; Fukuoka, Y.; Ikeda, H.; Tama, N.; Yamazaki, T.; et al. Association between matrix metalloproteinase-9 and worsening heart failure events in patients with chronic heart failure. ESC Heart Fail 2017, 4, 321-330. [CrossRef]

159. Sakai, N.; Wada, T.; Furuichi, K.; Shimizu, K.; Kokubo, S.; Hara, A.; Yamahana, J.; Okumura, T.; Matsushima, K.; Yokoyama, H.; et al. MCP-1/CCR2-dependent loop for fibrogenesis in human peripheral CD14-positive monocytes. J. Leukoc. Biol. 2006, 79, 555-563. [CrossRef]

160. Kruglov, E.A.; Nathanson, R.A.; Nguyen, T.; Dranoff, J.A. Secretion of MCP-1/CCL2 by bile duct epithelia induces myofibroblastic transdifferentiation of portal fibroblasts. Am. J. Physiol. Gastrointest Liver Physiol. 2006, 290, G765-G771. [CrossRef]

161. Haudek, S.B.; Xia, Y.; Huebener, P.; Lee, J.M.; Carlson, S.; Crawford, J.R.; Pilling, D.; Gomer, R.H.; Trial, J.; Frangogiannis, N.G.; et al. Bone marrow-derived fibroblast precursors mediate ischemic cardiomyopathy in mice. Proc. Natl. Acad. Sci. USA 2006, 103, 18284-18289. [CrossRef] [PubMed]

162. Haudek, S.B.; Cheng, J.; Du, J.; Wang, Y.; Hermosillo-Rodriguez, J.; Trial, J.; Taffet, G.E.; Entman, M.L. Monocytic fibroblast precursors mediate fibrosis in angiotensin-II-induced cardiac hypertrophy. J. Mol. Cell Cardiol. 2010, 49, 499-507. [CrossRef] [PubMed]

163. Jugdutt, B.I. Aging and Heart Failure: Mechanisms and Management; Springer Science + Buisness Media: New York, NY, USA, 2014; pp. 360-362.

164. Travers, J.G.; Kamal, F.A.; Robbins, J.; Yutzey, K.E.; Blaxall, B.C. Cardiac Fibrosis: The Fibroblast Awakens. Circ. Res. 2016, 118, 1021-1040. [CrossRef] [PubMed]

165. Sun, Y.; Weber, K.T. Infarct scar: A dynamic tissue. Cardiovasc. Res. 2000, 46, 250-256. [CrossRef]

166. Little, W.C.; Zile, M.R.; Kitzman, D.W.; Hundley, W.G.; O’Brien, T.X.; Degroof, R.C. The effect of alagebrium chloride (ALT-711), a novel glucose cross-link breaker, in the treatment of elderly patients with diastolic heart failure. J. Card Fail 2005, 11, 191-195. [CrossRef] [PubMed]

167. Hartog, J.W.; Willemsen, S.; van Veldhuisen, D.J.; Posma, J.L.; van Wijk, L.M.; Hummel, Y.M.; Hillege, H.L.; Voors, A.A.; investigators, B. Effects of alagebrium, an advanced glycation endproduct breaker, on exercise tolerance and cardiac function in patients with chronic heart failure. Eur. J. Heart Fail 2011, 13, 899-908. [CrossRef]

168. Tromp, J.; van der Pol, A.; Klip, I.T.; de Boer, R.A.; Jaarsma, T.; van Gilst, W.H.; Voors, A.A.; van Veldhuisen, D.J.; van der Meer, P. Fibrosis marker syndecan-1 and outcome in patients with heart failure with reduced and preserved ejection fraction. Circ. Heart Fail 2014, 7, 457-462. [CrossRef]

169. Bradshaw, A.D.; Baicu, C.F.; Rentz, T.J.; Van Laer, A.O.; Boggs, J.; Lacy, J.M.; Zile, M.R. Pressure overload-induced alterations in fibrillar collagen content and myocardial diastolic function: Role of secreted protein acidic and rich in cysteine (SPARC) in post-synthetic procollagen processing. Circulation 2009, 119, 269-280. [CrossRef]

170. Bradshaw, A.D.; Baicu, C.F.; Rentz, T.J.; Van Laer, A.O.; Bonnema, D.D.; Zile, M.R. Age-dependent alterations in fibrillar collagen content and myocardial diastolic function: Role of SPARC in post-synthetic procollagen processing. Am. J. Physiol. Heart Circ Physiol. 2010, 298, H614-H622. [CrossRef] 
171. Zuo, C.; Li, X.; Huang, J.; Chen, D.; Ji, K.; Yang, Y.; Xu, T.; Zhu, D.; Yan, C.; Gao, P. Osteoglycin attenuates cardiac fibrosis by suppressing cardiac myofibroblast proliferation and migration through antagonizing lysophosphatidic acid 3/matrix metalloproteinase 2/epidermal growth factor receptor signalling. Cardiovasc. Res. 2018, 114, 703-712. [CrossRef]

172. Stoddard, M.F.; Pearson, A.C.; Kern, M.J.; Ratcliff, J.; Mrosek, D.G.; Labovitz, A.J. Left ventricular diastolic function: Comparison of pulsed Doppler echocardiographic and hemodynamic indexes in subjects with and without coronary artery disease. J. Am. Coll. Cardiol. 1989, 13, 327-336. [CrossRef]

173. Raya, T.E.; Gay, R.G.; Lancaster, L.; Aguirre, M.; Moffett, C.; Goldman, S. Serial changes in left ventricular relaxation and chamber stiffness after large myocardial infarction in rats. Circulation 1988, 77, 1424-1431. [CrossRef] [PubMed]

174. Zile, M.R.; Baicu, C.F.; Gaasch, W.H. Diastolic heart failure-abnormalities in active relaxation and passive stiffness of the left ventricle. N. Engl. J. Med. 2004, 350, 1953-1959. [CrossRef] [PubMed]

175. van Heerebeek, L.; Paulus, W.J. Understanding heart failure with preserved ejection fraction: Where are we today? Neth. Heart J. 2016, 24, 227-236. [CrossRef] [PubMed]

176. Borbely, A.; van der Velden, J.; Papp, Z.; Bronzwaer, J.G.; Edes, I.; Stienen, G.J.; Paulus, W.J. Cardiomyocyte stiffness in diastolic heart failure. Circulation 2005, 111, 774-781. [CrossRef] [PubMed]

177. Linke, W.A.; Hamdani, N. Gigantic business: Titin properties and function through thick and thin. Circ. Res. 2014, 114, 1052-1068. [CrossRef] [PubMed]

178. He, H.; Giordano, F.J.; Hilal-Dandan, R.; Choi, D.J.; Rockman, H.A.; McDonough, P.M.; Bluhm, W.F.; Meyer, M.; Sayen, M.R.; Swanson, E.; et al. Overexpression of the rat sarcoplasmic reticulum Ca2+ ATPase gene in the heart of transgenic mice accelerates calcium transients and cardiac relaxation. J. Clin. Investig. 1997, 100, 380-389. [CrossRef]

179. Flesch, M.; Schwinger, R.H.; Schiffer, F.; Frank, K.; Sudkamp, M.; Kuhn-Regnier, F.; Arnold, G.; Bohm, M. Evidence for functional relevance of an enhanced expression of the $\mathrm{Na}(+)-\mathrm{Ca} 2+$ exchanger in failing human myocardium. Circulation 1996, 94, 992-1002. [CrossRef]

180. Makino, N.; Panagia, V.; Gupta, M.P.; Dhalla, N.S. Defects in sarcolemmal Ca2+ transport in hearts due to induction of calcium paradox. Circ. Res. 1988, 63, 313-321. [CrossRef]

181. Deluca, H.F.; Engstrom, G.W. Calcium uptake by rat kidney mitochondria. Proc. Natl. Acad. Sci. USA 1961, 47, 1744-1750. [CrossRef]

182. Nuss, H.B.; Houser, S.R. Sodium-calcium exchange-mediated contractions in feline ventricular myocytes. Am. J. Physiol. 1992, 263, H1161-H1169. [CrossRef] [PubMed] 